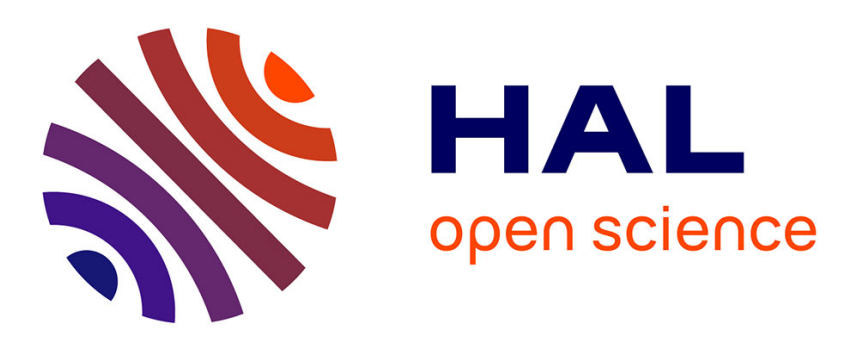

\title{
Effects of a broad range of experimental temperatures on the population growth and body-size of five species of free-living nematodes
}

Nabil Majdi, Walter Traunspurger, Hendrik Fueser, Birgit Gansfort, Pascal Laffaille, Anthony Maire

\section{To cite this version:}

Nabil Majdi, Walter Traunspurger, Hendrik Fueser, Birgit Gansfort, Pascal Laffaille, et al.. Effects of a broad range of experimental temperatures on the population growth and body-size of five species of free-living nematodes. Journal of Thermal Biology, In press, 10.1016/j.jtherbio.2018.12.010 . hal01961069

\section{HAL Id: hal-01961069 \\ https: / hal-edf.archives-ouvertes.fr/hal-01961069}

Submitted on 19 Dec 2018

HAL is a multi-disciplinary open access archive for the deposit and dissemination of scientific research documents, whether they are published or not. The documents may come from teaching and research institutions in France or abroad, or from public or private research centers.
L'archive ouverte pluridisciplinaire HAL, est destinée au dépôt et à la diffusion de documents scientifiques de niveau recherche, publiés ou non, émanant des établissements d'enseignement et de recherche français ou étrangers, des laboratoires publics ou privés. 


\title{
Effects of a broad range of experimental temperatures on the population growth and body-size of five species of free-living nematodes
}

\author{
Nabil MAJDI ${ }^{\mathrm{a}, \mathrm{b}, *}$, Walter TRAUNSPURGER ${ }^{\mathrm{a}}$, Hendrik FUESER ${ }^{\mathrm{a}}$, Birgit \\ GANSFORT $^{\mathrm{a}}$, Pascal LAFFAILLE $^{\mathrm{b}}$ and Anthony MAIRE ${ }^{\mathrm{c}}$
}

\section{Journal of Thermal Biology}

DOI: 10.1016/j.jtherbio.2018.12.010

\section{https://www.sciencedirect.com/science/article/pii/S0306456518304315}

${ }^{a}$ Bielefeld University, Animal Ecology, Bielefeld, Germany

${ }^{\mathrm{b}}$ EcoLab, Université de Toulouse, CNRS, INPT, UPS, Toulouse, France

${ }^{c}$ EDF R\&D LNHE - Laboratoire National d'Hydraulique et Environnement, Chatou, France

*Corresponding author - E-mail address: nabil.majdi@uni-bielefeld.de (N. Majdi).

\section{Publication History}

Received: 27 September 2018

Revised: 25 November 2018

Accepted: 9 December 2018

Version of record online: 15 December 2018

Issue online: 2019

NB: This version of the manuscript corresponds to the last version before proof-editing by the journal. Some changes made by the editor afterwards may not be present in this version. See online article on the journal's website for the final version of the article. 


\title{
HIGHLIGHTS
}

- Close nematode species can show contrasted growth patterns in response to temperature gradient.

- Body-size at maturity declines with increasing temperature.

- The number of eggs carried in the uterus declines with increasing temperature.

- Prevalence of early juvenile stages reduces body-mass structure with increasing temperature.

\begin{abstract}
The temperature-size rule postulates that the growth rates of ectotherms increase under rising temperatures, while the sizes of these organisms at maturity decrease. However, the upper temperature-tolerance range is also typically represented by a metabolic tipping point after which growth suddenly ceases. Free-living nematodes are important members of ecosystems, but little is known about their thermal tolerance. In the present study we measured the population growth rates and body-size distributions of five species of freeliving bacterivorous nematodes exposed in the laboratory to a broad range of temperatures. This allowed a determination of their different thermal tolerance ranges, even of closely related species, including Plectus acuminatus (thermal optimum of $20-25^{\circ} \mathrm{C}$ ) and P. cf. velox $\left(10-15^{\circ} \mathrm{C}\right)$. With the exception of Acrobeloides nanus, which had the broadest thermal tolerance range, the population growth of the other species declined between 25 and $30^{\circ} \mathrm{C}$. Our results were consistent with the temperature-size rule, as the body-size of the tested species at maturity decreased with increasing temperature. This reduction was accompanied by a smaller number of eggs carried by mature females. Although our study was purely experimental, it suggests that heat waves or other alterations in the thermal regime affect the population dynamics and body-size structure of nematode communities in the field.
\end{abstract}

KEY WORDS: Plectus; Acrobeloides; thermal tolerance; warming; life history; body-size distribution

\section{INTRODUCTION}

Increases in the mean and maximum temperatures and in the frequency of extreme climatic events are among the consequences of climate change (IPCC, 2014). Because life-history traits may be differentially affected by warming (e.g. reduced lifespan, but higher rate of offspring production), the population growth response, as the summation of several temperature-sensitive processes (Savage et al., 2004; Bingemer et al., 2016; Lindmark et al., 2018), may be the most appropriate measure of optimum temperature. Ectothermic species (i.e. poikilothermic species having the same body temperature as their environment) tend to grow quicker, but to hatch and mature at smaller bodysizes, as the temperature increases (at least within their thermal tolerance range). Consequently, temperature-mediated changes in body-size are another appropriate endpoint to consider in warming experiments (Van der Have and De Jong, 1996; Angilletta Jr et al., 2004). Changes in the body-size spectrum of a species and the multigenerational response of the life-history traits of that species to an altered temperature regime are likely to affect the functional structure of the broader community and thus the functioning of the respective ecosystem as well (e.g. in freshwater ecosystems see Woodward et al., 2010, 2016; O'Gorman et al., 2012).

Nematodes have several advantages as model organisms in studies of the response to changing temperatures, as they are ectothermic, extremely diverse, central to ecosystem functioning and highly abundant, colonizing all substrates examined thus far (Traunspurger, 2000; Yeates et al., 2009). Free- 
living nematodes are intermediaries in food webs, feeding on bacteria, fungi, algae, and protists but also preyed upon by many animals, from invertebrates to vertebrates (Yeates et al., 1993; Majdi and Traunspurger, 2015). Nematode reproduction includes species able to reproduce continuously by parthenogenesis (Baldwin and Perry, 2004). Nematode population growth may be limited by physical (e.g., habitat-size, oxygen availability) or biological (e.g., resource availability) factors, but it is strongly reliant on the ambient temperature (Lee, 2002). Although much remains to be learned about the thermal physiology and ecology of free-living nematodes, each nematode species presumably has an optimal temperature range, one that favors population growth and is generally consistent with its biogeographic distribution (Anderson and Coleman, 1982; Venette and Ferris, 1997). Outside this thermal optimum, metabolic rates are altered and egg development may be delayed or cease until more favorable conditions return (Wharton, 2002; Ayub et al., 2013).

However, there are also nematode species whose habitats are characterized by temperature extremes or fluctuations. For example, the terrestrial species Panagrolaimus davidi can survive subzero temperatures (Smith et al., 2008), while a few nematode species have been found dwelling in the biofilms of mineral springs, where temperatures range from 10 to $40{ }^{\circ} \mathrm{C}$ (Ocaña, 1991). Nematode populations coping with extreme temperature fluctuations overcome the associated challenges by shifting their life-history traits (diapause, anhydrobiosis, dauer larval stage), reproduction strategy (egg dormancy, changing sex ratios) or behavior (migration, aggregation) (see reviews of Wharton, 2002; McSorley, 2003; Tahseen, 2012). As an example, adults of Plectus parietinus and Plectus velox can enter anhydrobiosis (i.e., a dry dormant stage) to survive the complete dehydration of their habitats (Sandhove et al., 2016).

Despite the ability of nematodes to thrive under a broad range of temperatures, the temperature dependence of these organisms implies that their population dynamics and community structure might be influenced by the local and global effects of climate change and by anthropogenic activities (Freckman and Virginia, 1997; Ruess et al., 1999; Yeates and Boag, 2003; Kim et al. 2013). In the last 100 years, the Earth's average surface temperature has risen by $0.85{ }^{\circ} \mathrm{C}$, and a further increase is now ineluctable (IPCC, 2014). However, for populations of fast-reproducing but quasi-sessile species of small animals, the broader temperature extremes and fluctuations that occur at smaller spatial and temporal scales have more immediate implications for survival (Vafeiadou et al., 2018). Yet, in the case of free-living nematodes, our ability to predict the effects of temperature changes on their populations is very limited, partly because little is known about their thermal biology (but see Anderson and Coleman, 1982; Venette and Ferris, 1997). Understanding the response of nematode population growth rates to warming temperatures under standard laboratory conditions will improve predictions regarding nematode population dynamics in the field (Jager et al., 2005).

In this study, we measured the population growth and body-size structure of five widespread, freeliving, bacterivorous nematode species: namely, the relatively large Plectus cf. velox, medium-sized Plectus acuminatus, and Plectus aquatilis, and minute Plectus opisthocirculus and Acrobeloides nanus, cultured under constant laboratory-controlled temperatures ranging from 10 to $35^{\circ} \mathrm{C}$. We first set out to identify the thermal optimum of each species and thus define the thermal niche of each one. Based on energy conservation rules, we predicted that larger species would achieve higher growth rates at lower temperatures and vice versa. Furthermore, since all of the studied nematode species populations have been cultivated for years (i.e. dozens of generations) under standard laboratory conditions at a constant temperature of $20^{\circ} \mathrm{C}$ (Kreuzinger-Janik et al., 2017; Gansfort et al., 2018), we expected that each species would have an optimal growth temperature of $20{ }^{\circ} \mathrm{C}$. Deviation from 
this thermal optimum could reveal deep evolutionary roots to thermal tolerance mechanisms in the species investigated. We also predicted that nematode responses to warming would follow universal ecological rules (like the temperature-size-rule and its corollaries as formulated e.g. in Daufresne et al., 2009). For example, at the individual level an age-specific (e.g. in adults) decrease in individual body-size, and at the population-level a decrease in mean body-size due to an increase in the proportion of juveniles were expected.

\section{MATERIAL AND METHODS}

\subsection{Nematode stock cultures}

The five species of free-living bacterivorous nematodes used in this study included four semi-aquatic species from the genus Plectus (Plectus acuminatus, Plectus aquatilis, Plectus opisthocirculus, and Plectus cf. velox), obtained as wild isolates from the Lake Constance (Germany) littoral, and the small terrestrial species Acrobeloides nanus, was obtained as wild isolate from young soils at Berzdorf (Germany). All species have been maintained in our laboratory for several years at $20{ }^{\circ} \mathrm{C}$ in the dark on "sloppy" agar plates (1\%) with a low salt content. For this study, the nematodes were fed with Escherichia coli strain OP50, a uracil-requiring strain used to prevent bacterial overgrowth. Bacterial densities in the nematode stock cultures were adjusted spectrophotometrically to $10^{9}-10^{10}$ cells $\mathrm{mL}^{-1}$, a density determined to be optimal for many bacterivorous nematode species (see Kreuzinger-Janik et al., 2017 and references therein). Prior to the experiments, the nematodes were transferred to Petri dishes containing semi-solid gellan gum medium (see composition below) for acclimation. All laboratory procedures were carried out under sterile conditions.

\subsection{Nematode growth medium}

Component nematode growth gellan gum (CNGG) was used as the medium for the experiments, after Brinke et al. (2013). In addition to its lower salt content (including a lack of $\mathrm{NaCl}$ ), CNGG medium solidifies in the presence of (divalent) cations, such as magnesium or calcium. Gelation is thus initiated by mixing cold solutions of gellan gum and salts. The advantages of CNGG is that fresh medium can be prepared at any time from previously autoclaved, separate solutions, and bacterial food is easily and homogeneously mixed into the medium if salts are added in the last step. As food, $E$. coli was added to the medium at a concentration of $1 \times 10^{9}$ cells $\mathrm{mL}^{-1}$ in. To prepare $5 \mathrm{~mL}$ of CNGG, a bacterial pellet containing $5 \times 10^{9}$ cells $\mathrm{mL}^{-1}$ was mixed with $4.2 \mathrm{~mL}$ of the gellan gum solution (1.9 $\mathrm{g} \mathrm{L}^{-1}$ Gelrite ${ }^{\circledR}$, with $1.25 \mathrm{~mL}$ cholesterol solution $\left(5 \mathrm{mg} \mathrm{mL}^{-1}\right.$ in ethanol) added after autoclaving). After the addition of $800 \mu \mathrm{L}$ of salt solution $(10 \mathrm{mM} \mathrm{MgSO}$, $10 \mathrm{mM} \mathrm{CaCl}$ ), the resulting CNGG medium was mixed for $30 \mathrm{~s}$ before it was added to the standard 6-well sterile multiwell plates (VWR $®$ tissue culture plates 734-2323) used in the experiment.

\subsection{Experimental design}

For each nematode species and temperature condition, 5 replicates ( $4 \mathrm{~mL}$ of CNGG per well) were prepared in each 6-well plate. The sixth well was filled with $4 \mathrm{~mL}$ of distilled water to prevent evaporation during the course of the experiment (Fig. A.1). Nematodes from stock cultures were sieved on 35- $\mu \mathrm{m}$ meshes, the largest individuals (mostly adults) that did not pass through the meshes 
were rinsed with Volvic ${ }^{\circledR}$ water from the sieve surface into a clean beaker. Fifty living adults were gently lifted with a mouth pipette under stereomicroscopy (magnification 40x) guidance and immediately placed in the individual wells ( 5 replicates $\times 50$ nematodes $\times 6$ temperatures $\times 5$ species $=7500$ adults; see Fig. A.1). After inoculation of the 50 starting adult individuals, each multi-well plate was sealed with Parafilm ${ }^{\circledR}$ and placed in the dark in temperature-controlled chambers set at the test temperatures of $10,15,20,25,30$ and $35^{\circ} \mathrm{C}\left( \pm 0.2^{\circ} \mathrm{C}\right)$. The experiment ran for 20 days with subsamplings every 5 days.

\subsection{Sub-sampling}

At each sub-sampling (i.e. $+5,+10,+15$, and +20 days), the plates were opened under a laminar airflow sterile bench and the amount of evaporated water in the first well was measured and, when necessary, compensated in all respective wells. Then the CNGG medium of each well was homogenized and liquefied by repeated pipetting using a 5-mL pipette set to $1 \mathrm{~mL}$ and with a tip widened by cutting its end. After $20 \mathrm{~s}$ of mixing, $1 \mathrm{~mL}$ was sampled and placed in a 15 -mL Falcon tube. Because the chelating agent EDTA breaks the bonds in the CNGG matrix (Muschiol and Traunspurger, 2007), $4 \mathrm{~mL}$ of an EDTA-Rose Bengal solution (0.93 g of 0.02 M EDTA, 0.15 g Rose Bengal in $500 \mathrm{~mL}$ of deionized water) was added to the tube to liquefy the CNGG medium and stain the nematodes to facilitate their counting. The nematodes were killed by heating the tubes at $80{ }^{\circ} \mathrm{C}$ for $30 \mathrm{~min}$ and then stored for a maximum of 10 days at $4{ }^{\circ} \mathrm{C}$ in the dark before counting. One $\mathrm{mL}$ of CNGG with fresh $E$. coli food was then added to each well to replace the sub-sampled volume and reduce food/space limitation constraints. The plates were sealed again and incubated. Sample processing outside the climate chamber did not exceed $10 \mathrm{~min}$ for each plate. At day +20 , the remaining CNGG medium was placed in $10 \mathrm{~mL}$ of EDTA solution for $30 \mathrm{~min}$, before the final population was rinsed in EDTA by centrifugation and then preserved in $2 \%$ formaldehyde.

\subsection{Sample analysis}

Each stained sample was poured whole into a Petri dish $(9.3 \mathrm{~mm} \times 15 \mathrm{~mm})$, under which a millimeter grid was printed. Using a stereomicroscope (40× magnification), the dish was screened and the nematodes were counted. In dishes with abundances $>200$ individuals, subsamples were counted. Density was expressed as the number of individuals per mL CNGG medium. At day $+20,60$ calibrated photos of the population of A. nanus were taken and then processed with ImageJ software, to measure the maximum length and width of the population. The relatively large number of individuals in the A. nanus samples allowed a comparison of the size-spectrum of the population after 20 days exposure to temperatures of 20,25 and $30{ }^{\circ} \mathrm{C}(\mathrm{N}=1732$ individuals measured $)$. Individual dry weight (ind. DW) was estimated using the formula of Andrássy (1956) and a dry :wet ratio of 0.25 (Wieser, 1960). At day +20 , adult specimens of all species were removed from the samples and mounted on slides following the method of Seinhorst (1959). The number of eggs in the uterus of female individuals was counted and the maximum body length measured at $400 \times$ magnification, using a reticle in the ocular of a Leitz ${ }^{\circledR}$ Dialux 20 microscope. 


\subsection{Calculation of population growth rates}

The development of population densities over time can be described by the exponential growth function (Ricklefs and Miller, 1999). Therefore, we plotted the densities determined in each well over time (in days) and then calculated the $\mathrm{R}^{2}$ and the parameters of an exponential function for each replicate well. From the 150 exponential relationships ( 5 replicates $\times 6$ temperature $\times 5$ species), $90 \%$ had $\mathrm{R}^{2}$-values $>0.5$. According to the exponential growth function, the number of individuals in a population based on an initial population $\mathrm{N}_{0}$ after $t$ days can be calculated as:

$$
N_{t}=N_{0} \times e^{r t}
$$

where $r$ is the intrinsic growth rate of the population, also called the intrinsic rate of natural increase (Birch, 1948).

Given the artificial "mortality" induced by the removal of $25 \%$ of the medium during sub-sampling on days 5,10 , and 15 , the formula had to be adapted to avoid underestimation of the growth rate (see details in Gansfort et al., 2018). After 5 days the "new" population is calculated as:

$$
N_{5}=N_{0} \times e^{r 5}
$$

From that number, $25 \%$ of the individuals were removed while $75 \%$ remained in the wells and continued to grow. This resulted in the following formula expressing the number of individuals after 10 days (5 days after day 5).

$$
N_{10}=N_{0} \times 0.75 \times e^{r 10}
$$

Accordingly, after 15 and 20 days, the number of individuals could be calculated as follows:

$$
\begin{aligned}
& N_{15}=N_{0} \times 0.75^{2} \times e^{r 15} \\
& N_{20}=N_{0} \times 0.75^{3} \times e^{r 20}
\end{aligned}
$$

Applying $\ln$ on each side allowed calculation of the intrinsic growth rate $r$ :

$$
r=\frac{\ln \left(N_{20}\right)-\ln \left(N_{0}\right)-\ln \left(0.75^{3}\right)}{20} \leftrightarrow r=\frac{\ln \left(N_{20}\right)-\ln \left(N_{0}\right)}{20}+0.0432
$$

The last transformation illustrates that artificial mortality after 20 days is adequately represented by the inclusion of a factor of 0.0432 , thus allowing correction of the measured growth rate for medium and individual removal. Note that for P. opisthocirculus, two instead of three sub-samples were taken, because at +15 days the population had grown so slowly that renewal of a part of the medium was deemed unnecessary. Therefore, the correction of $r$ was smaller in this case: $\ln \left(0.75^{2}\right) / 20=0.0288$.

\subsection{Data analysis}

The influence of temperature on the growth rate of each species was compared using the nonparametric Kruskal-Wallis rank sum test (KW test) with Dunn's post-hoc comparisons and a p-value adjusted for multiple comparisons using a Holm-Bonferroni correction. Polynomial regression curves with $95 \%$ confidence intervals were fitted on population growth rate data. A KW test with a pairwise Wilcoxon signed rank test was used to test for significant differences across temperatures with respect to the number of eggs in the uterus of mature females and for differences in female body-length. For A. nanus, the size-structure of the population at 20,25 and $30^{\circ} \mathrm{C}$ was compared using a $\mathrm{KW}$ test and a Wilcoxon signed rank test. To control for the rate of false discoveries amongst the rejected 
hypotheses, the p-values in the Wilcoxon comparisons were adjusted using the BH method of Benjamini and Yekutieli (2001). All statistical analyses and graphical representations were carried out using R software (R Development Core Team, 2018), including the packages MASS, dunn.test, and vegan for statistics and dplyr, ggplot 2 , and ggpubr for graphical representations.

\section{RESULTS}

\subsection{Effect of temperature on the growth rate of each species}

The growth rates of Plectus acuminatus, Plectus aquatilis and Plectus opisthocirculus followed a similar pattern with respect to temperature, with growth peaking at $20-25{ }^{\circ} \mathrm{C}$ before decreasing sharply at higher temperatures (Fig. 1). For those species, no individuals were found alive after 5 days of exposure to a temperature of $35^{\circ} \mathrm{C}$, and population growth was fairly low at 10 and $30{ }^{\circ} \mathrm{C}$. The univariate results of the statistical tests, shown in the Appendix (Table B.1), revealed significant differences in the growth rates of the nematodes between the extreme $\left(10\right.$ and $\left.35^{\circ} \mathrm{C}\right)$ and the optimum (20 and $25{ }^{\circ} \mathrm{C}$ ) temperatures. In addition, the difference in the growth rate at 25 vs. $30{ }^{\circ} \mathrm{C}$ was significant for $P$. acuminatus and $P$. opisthocirculus (Table B.1), and marginally significant for $P$. aquatilis $\left(\mathrm{P}_{\text {adjusted }}=0.052\right)$. For those three species, the results suggested the existence of a metabolic tipping point between 25 and $30^{\circ} \mathrm{C}$.

The pattern observed for Plectus cf. velox differed, as this species also grew well at the colder temperatures $\left(10\right.$ and $\left.15^{\circ} \mathrm{C}\right)$. For $A$. nanus, population growth peaked at $25-30{ }^{\circ} \mathrm{C}$ before collapsing at $35^{\circ} \mathrm{C}$ (Table B.1), but this was the only species in which individuals were still found alive after 20 days of exposure to $35^{\circ} \mathrm{C}$. 


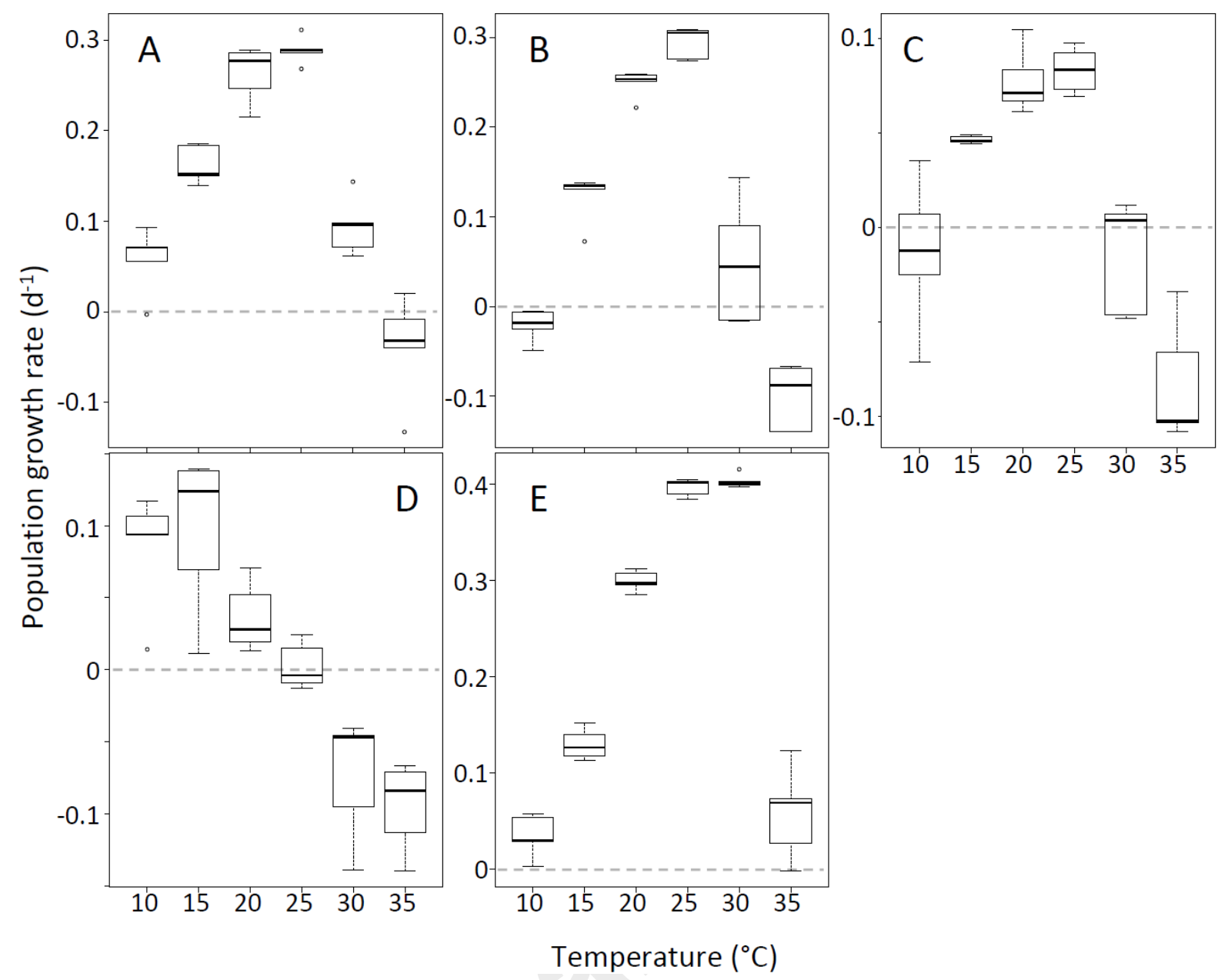

Fig. 1. Population growth rates of five species of nematodes cultured under a broad range of temperatures: (A) Plectus acuminatus, (B) Plectus aquatilis, (C) Plectus opisthocirculus, (D) Plectus cf. velox, and (E) Acrobeloides nanus. Values are medians, and boxes the interquartile range. Negative growth (i.e. population collapse) occurs under the dotted line.

\subsection{Comparis on of species' performance at $10-35{ }^{\circ} \mathrm{C}$}

At $10{ }^{\circ} \mathrm{C}$, the large cryophilic Plectus cf. velox performed better than $P$. aquatilis and $P$. opisthocirculus (Figs 2 and B.1). Interestingly, P. acuminatus also performed well at $10{ }^{\circ} \mathrm{C}$ and better than $P$. aquatilis, while the growth pattern of the two species was similar at higher temperatures (see Table B.2 for statistical comparisons). At $15{ }^{\circ} \mathrm{C}$, P. opisthocirculus stood out because of its weak growth, but this species did not grow as well as the others under all conditions tested. At $20{ }^{\circ} \mathrm{C}$, the growth rates of $P$. opisthocirculus and $P$. cf. velox were far slower than those of the other species. At $25{ }^{\circ} \mathrm{C}$, A. nanus had the highest growth rate, although $P$. acuminatus and $P$. aquatilis continued to grow well. At $30{ }^{\circ} \mathrm{C}$, the growth rate of the minute thermophilic A. nanus peaked while that of all other species diminished. At $35^{\circ} \mathrm{C}$, as noted above, A. nanus was the only species still alive after 20 days and its population growth rate was still positive. 


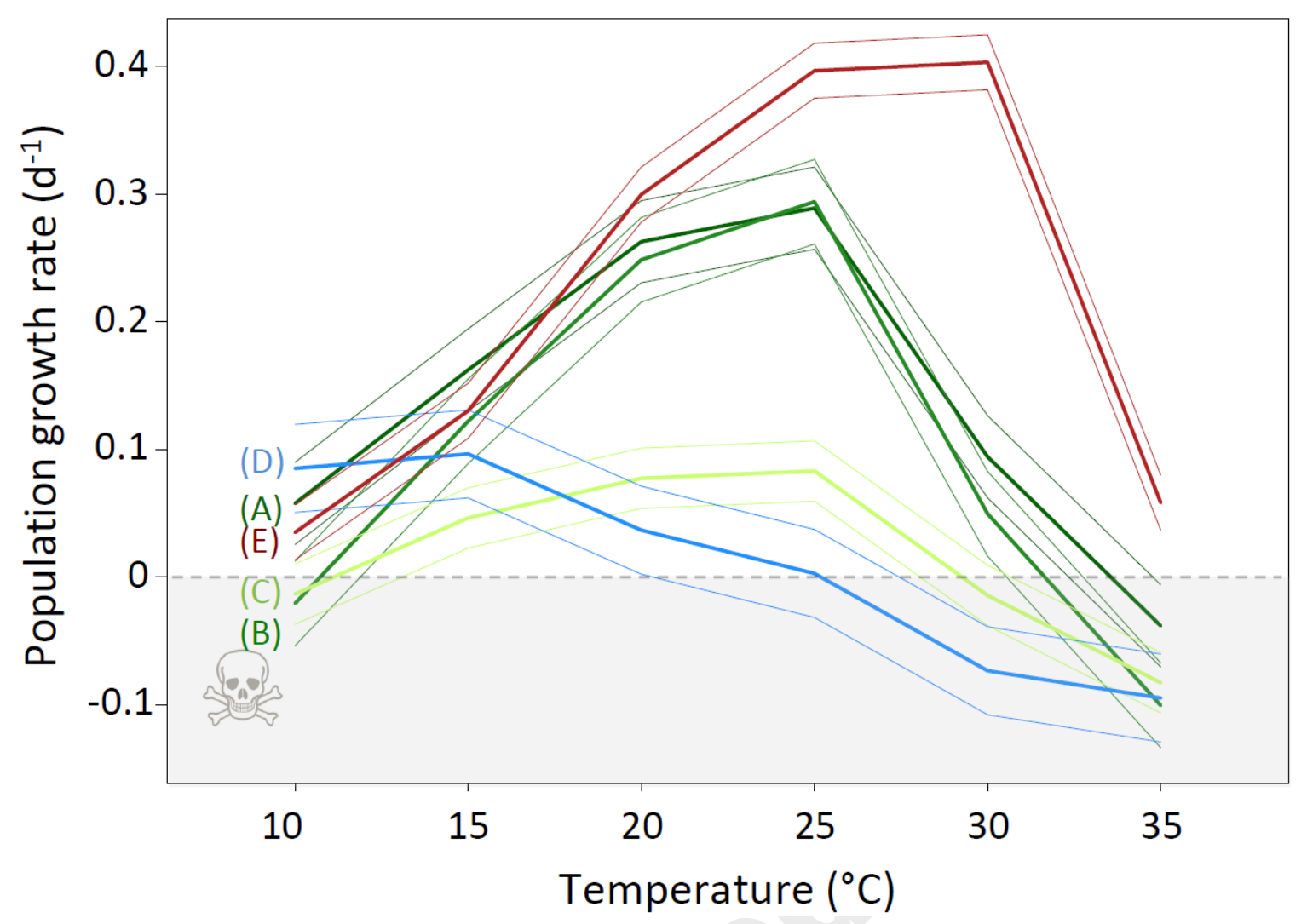

Fig. 2. Polynomial regression fit ( $\pm 95 \%$ confidence interval) of the population growth rate of five species of nematodes cultured under a broad range of temperatures. (A) Plectus acuminatus, (B) Plectus aquatilis, (C) Plectus opisthocirculus, (D) Plectus cf. velox, and (E) Acrobeloides nanus. Negative growth (i.e. population collapse) occurs under the dotted line.

\subsection{Effect of temperature on the number of eggs and on body-size at maturity}

Both the number of eggs present in the uterus of female nematodes and the body-length of mature females allowed very small species with low numbers of eggs (Plectus opisthocirculus and Acrobeloides nanus) to be distinguished from the larger Plectus acuminatus and P. aquatilis, whose females carried many more eggs and had a body-size more than twice as long (Figs C.1 and C.2). The highest number of eggs were in Plectus cf. velox females (mean of 6.96 eggs female $^{-1}$, max. of 15). This species was also the largest at maturity (mean body-length of $1504 \mu \mathrm{m}$, max. $1772 \mu \mathrm{m}$ ). The number of eggs in the uterus of A. nanus females was very low under all tested conditions, whereas for the other four species the differences in the number of eggs was significant at all temperatures $\left(\mathrm{KW} \chi^{2}>11.4, \mathrm{p}<0.02\right)$. In P. acuminatus and P. aquatilis, the number of eggs peaked at $20{ }^{\circ} \mathrm{C}$ and then decreased (Fig. 3). In P. opisthocirculus, the number of eggs increased and in $P$. cf. velox it decreased with increasing temperature (Fig. 3). 


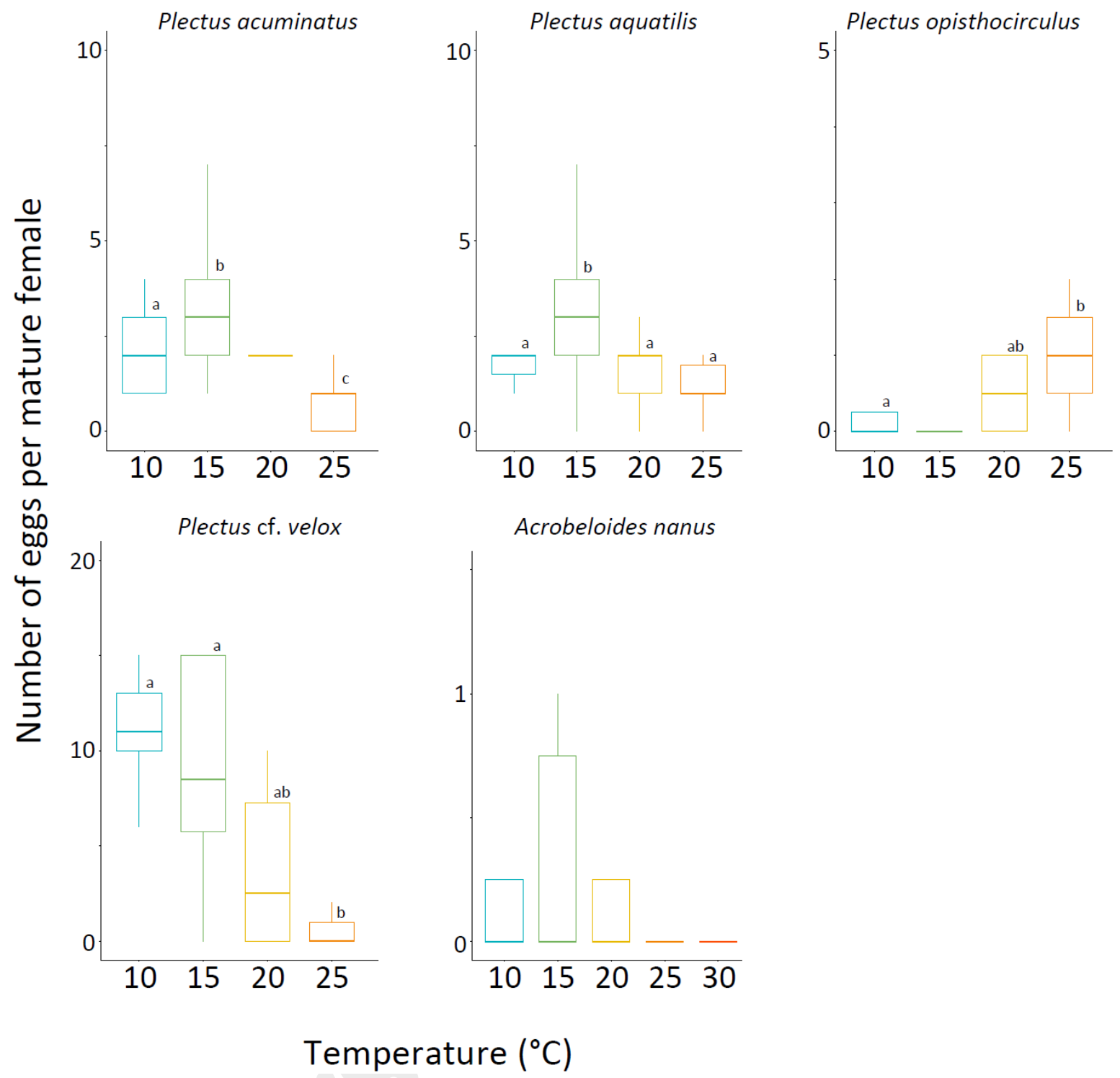

Fig. 3. Number of eggs in the uterus of mature females $(N=420)$ from five species of nematodes cultured under a broad range of temperatures. Different letters indicate significant differences in pairwise comparisons.

Body-length at maturity was significantly affected by temperature in all five nematode species (KW $\left.\chi^{2}>12.1, \mathrm{p}<0.01\right)$. The body-lengths of $P$. acuminatus and A. nanus tended to decrease with increasing temperature, whereas for $P$. aquatilis and $P$. opisthocirculus length at maturity decreased significantly between 25 and $30^{\circ} \mathrm{C}$ (Fig. 4). 


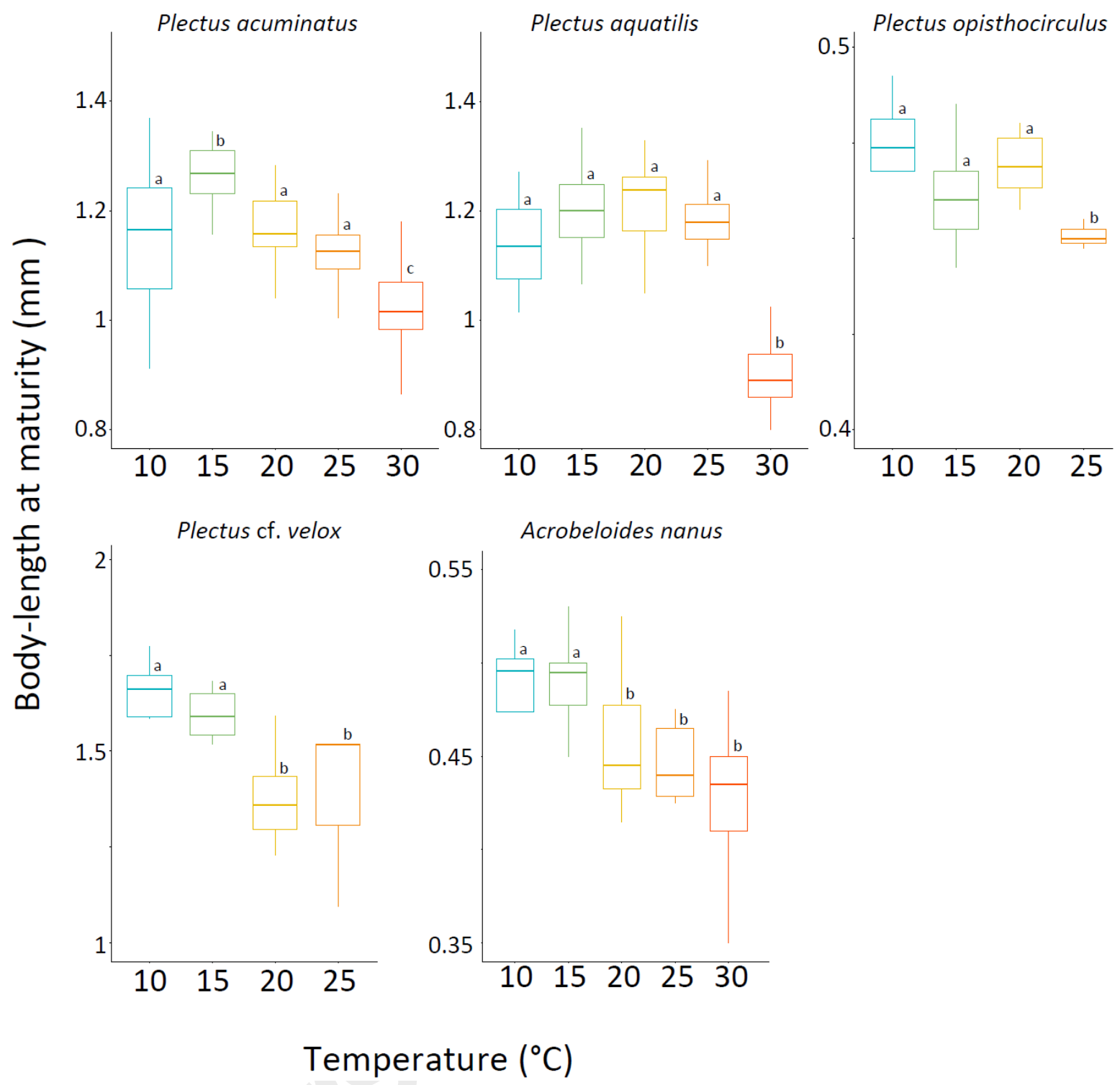

Fig. 4. Body-length of mature females $(N=420)$ from five species of nematodes cultured under a broad range of temperatures. Different letters indicate significant differences in pairwise comparisons.

\subsection{Effect of temperature on the population size spectrum of $A$. nanus}

Within a population, individual body-mass was significantly greater at $20{ }^{\circ} \mathrm{C}$ than at 25 and $30{ }^{\circ} \mathrm{C}$ (medians of 6.66, 2.91 and $3.06 \mathrm{ngDW}$ ind. ${ }^{-1}$ at 20,25 and $30^{\circ} \mathrm{C}$, respectively, $\mathrm{KW} \chi^{2}=163.5, \mathrm{p}<$ 0.001, see Fig. 5). This reduction was due to a higher proportion of early juvenile stages at 25 and 30 ${ }^{\circ} \mathrm{C}$ (individuals weighing roughly between 0.4 and $5 \mathrm{ngDW}$; see the changes in the population bodymass spectra in Fig. D.1). 


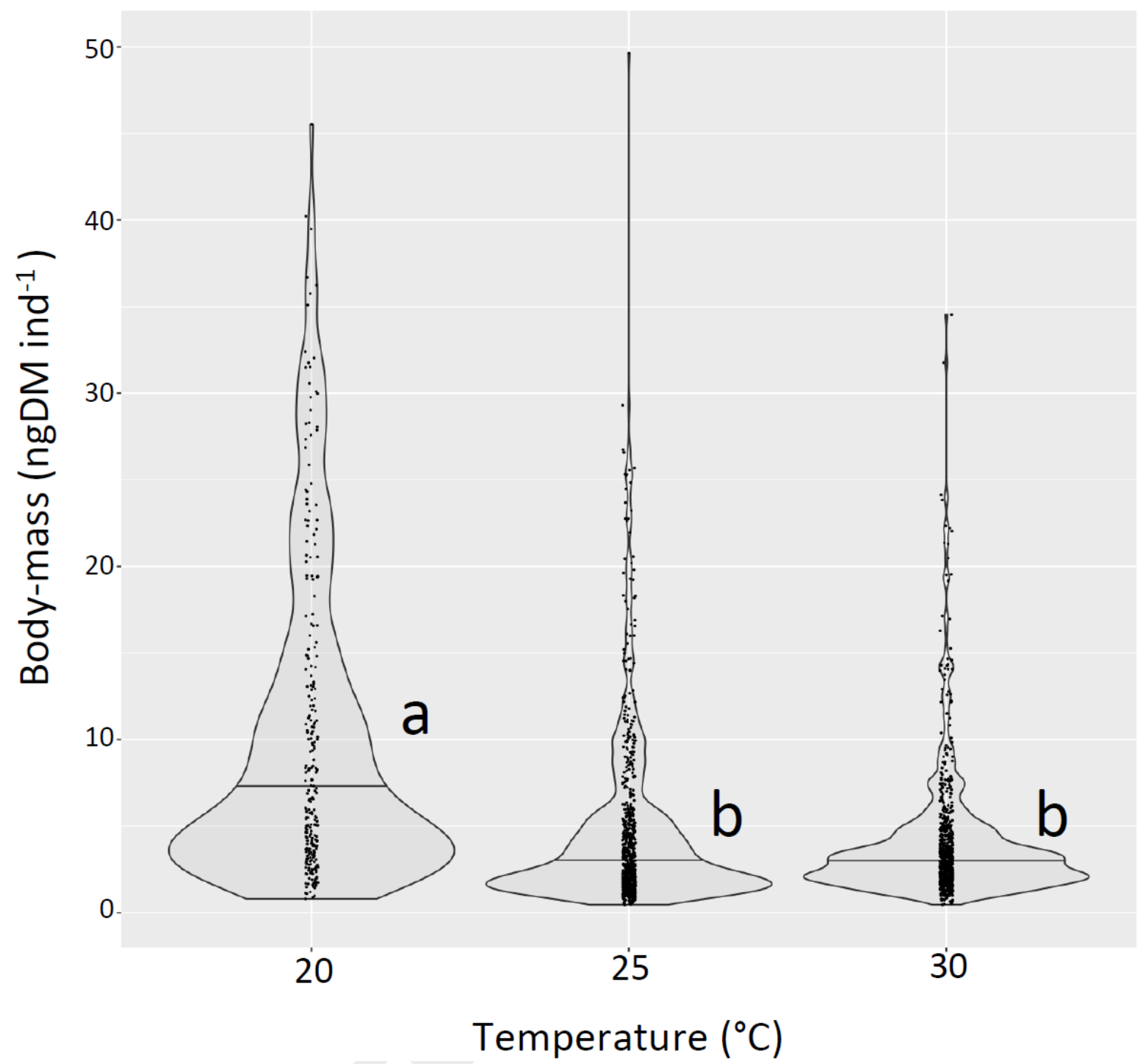

Fig. 5. Individual dry mass (DM) in populations of the nematode A. nanus cultured at 20, 25 and 30 ${ }^{\circ} \mathrm{C}$. Violin plots show the probability density distribution on each side, as well as the median values. Points are samples. Different letters indicate significant differences in pairwise comparisons.

\section{DISCUSSION}

The population growth rate is an important unifying variable in ecology allowing a better understanding of the effects of environmental stress (e.g., climate change), because negative growth rates influence the boundaries of a species' ecological niche (Sibly and Hone, 2002). In nematodes and many other species, population growth reflects the sum of many temperature-sensitive processes, including changes in lifespan, rate of development, egg production, hatching success, and generation time (Pillai and Taylor, 1967; Sohlenius, 1968; Hopper et al., 1973; Trudgill and Perry, 1994; Ruess et al., 1999; Lee, 2002). Our results show that the population growth rates of different species of freeliving bacterivorous nematodes may differ in their thermal optima and thermal tolerance ranges. As demonstrated in this study, this is also true for phylogenetically close species or species that have been maintained for many generations under the same standard laboratory conditions $\left(20^{\circ} \mathrm{C}\right)$. Tipping points for population growth between 25 and $30{ }^{\circ} \mathrm{C}$ occurred in the three species of Plectus (P. 
acuminatus, $P$. aquatilis and $P$. opisthocirculus), and between 30 and $35{ }^{\circ} \mathrm{C}$ for $A$. nanus. This pattern is typical of temperature-dependent processes, as the thermal response of a species' growth rate can be interpreted in terms of enzyme kinetics, as done by Sharpe \& DeMichele (1977). Those authors derived a model describing a tipping point for growth based on the sudden temperature-dependent inactivation of a hypothetical enzyme limiting major aspects of development, such as cell division and differentiation.

Our study is the first to report the temperature-related population growth rates of Plectidae (see Table 1). Plectidae are widely distributed in terrestrial and freshwater ecosystems, they are also frequently found in habitats subject to extreme environmental stresses, including mosses that endure dry periods, polar and alpine soils, with their cycles of freezing and thawing, and hot springs, with their very high temperatures (e.g. Ocaña, 1991; Sohlenius et al., 1995). Plectidae have unique anhydrobiotic capabilities and a longer lifespan than members of the Rhabditidae and Cephalobidae, and they produce more eggs (Sandhove et al., 2016; Kreuzinger-Janik et al., 2017). These properties could provide an advantage in cold and dry habitats. In our study, Plectus cf. velox was the largest species and the one most tolerant of cold conditions; however, the other Plectus species (i.e. P. acuminatus, $P$. aquatilis and $P$. opisthocirculus) were not particularly tolerant of either cold or very hot temperatures. Why Plectus aquatilis was found to persist in hot springs at $40-42{ }^{\circ} \mathrm{C}$ after Ocaña (1991), is unclear. One hypothesis is that thermal adaptation in species is different from thermal adaptation in populations (see discussion in Moens and Vincx, 2000). The tolerance of wild nematode populations might fit the local environmental conditions, and thus we recommend longer-term experiments conducted using different wild population strains to better delineate species tolerance range. Furthermore, the nematodes in our study had become acclimated to standardized media, constant temperatures, and one type of food-conditions that are quite different from the natural environment. Thus, the reported population growth rates likely represent the current characteristics of the laboratory populations rather than the full range of species' plasticity. Indeed, in the field, numerous other additional abiotic and biotic factors (e.g. moisture, oxygen concentration, food concentration and quality, presence of predators and competitors) play a role and are expected to change in synergy with changes in the temperature regime and thereby impact the population growth rate as well. Nonetheless, our measures provide a standard with which to determine the direct impact of temperature on population growth. 
Table 1. Comparison of lower, optimum, and upper temperature thresholds measured in different species of free-living bacterivorous nematodes (listed by increasing temperature optima). The reported thresholds were determined based on empirically observed negative population growth rates or rapid declines in population numbers. Optima were defined from the maximum population growth rates measured across a broad range of experimental temperatures. Maximum population growth rates, reported as the maximum intrinsic rate of population growth $\left(r_{\max }\right)$, are based on data from this study (shown in bold) and from published material. The column 'Habitat' refers to the environment where the species was initially isolated from prior to laboratory rearing/culture.

\begin{tabular}{|c|c|c|c|c|c|c|c|c|c|}
\hline Species & $\begin{array}{l}\text { Low } \\
\mathrm{T}^{\circ} \mathrm{C}\end{array}$ & Optimum & $\begin{array}{l}\mathrm{Up} \\
\mathrm{T}^{\circ} \mathrm{C}\end{array}$ & Habitat & Location & $\begin{array}{l}\mathrm{T}^{\circ} \mathrm{C} \text { range } \\
\text { tested }\end{array}$ & $\begin{array}{l}\text { Culture medium, food, and data analysis } \\
\text { methodology }\end{array}$ & $\begin{array}{l}r_{\max } \\
\left(\mathrm{d}^{-1}\right)\end{array}$ & Reference \\
\hline Diplolaimelloides bruciei & 5 & 12.5 & 25 & marine & Lynther Estuary, UK & $5-30$ & DifcoCorne Agar. field bacteria. Measure of generation time & nd & Warwick 1981 \\
\hline Pelodera sp2 & 5 & 15 & 30 & soil & $\mathrm{CO}, \mathrm{USA}$ & $10-40$ & $1.5 \%$ Agar. Pseudomonas cepacia. Counts over 1 -mo period & nd & Anderson \& Coleman 1982 \\
\hline Plectus cf. velox & $<10$ & 15 & 25 & freshwater & Lake Constance, Germany & $10-35$ & NGG. Ecoli. intrinsic growth rate. polynomial regression fit & 0.14 & This study \\
\hline Rhabditis cucumeris & 4 & 17.7 & 24.8 & soil & CA, USA & $10-35$ & NGM. Ecoli. Schoolfield's poikilotherm model & $0.9^{*}$ & Venette \& Ferris 1997 \\
\hline Mesodiplogaster lheritieri & 10 & 20 & 30 & soil & $\mathrm{CO}, \mathrm{USA}$ & $10-40$ & $1.5 \%$ Agar. Pseudomonas cepacia. Counts over 1 -mo period & nd & Anderson \& Coleman 1982 \\
\hline Litoditis marina & 15 & 20 & 30 & marine & Westerschelde, The Netherlands & $5-35$ & 1\% BactoAgar. field bacteria. Q10 & nd & Moens \& Vincx 2000 \\
\hline Caenorhabditis elegans & 5.9 & 21.1 & 28.2 & soil & CA, USA & $10-35$ & NGM. Ecoli. Schoolfield's poikilotherm model & $1.57 *$ & Venette \& Ferris 1997 \\
\hline Rhabditis sp. & 10 & 24 & 35 & soil & $\mathrm{CO}, \mathrm{USA}$ & $10-40$ & $1.5 \%$ Agar. Pseudomonas cepacia. Counts over 1-mo period & nd & Anderson \& Coleman 1982 \\
\hline Pelodera spl & 20 & 24 & 35 & soil & MO, USA & $10-40$ & $1.5 \%$ Agar. Pseudomonas cepacia. Counts over 1-mo period & nd & Anderson \& Coleman 1982 \\
\hline Caenorhabditis sp. & 5 & 24 & 30 & soil & $\mathrm{CO}, \mathrm{USA}$ & $10-40$ & $1.5 \%$ Agar. Pseudomonas cepacia. Counts over 1-mo period & nd & Anderson \& Coleman 1982 \\
\hline Acrobeloides sp. & 5 & 24 & 35 & soil & $\mathrm{CO}, \mathrm{USA}$ & $10-40$ & $1.5 \%$ Agar. Pseudomonas cepacia. Counts over 1 -mo period & nd & Anderson \& Coleman 1982 \\
\hline Diplolaimelloides meyli & 10 & 25 & 35 & marine & Westerschelde, The Netherlands & $5-35$ & 1\% BactoAgar. field bacteria. Q10 & nd & Moens \& Vincx 2000 \\
\hline Plectus acuminatus & $<10$ & 25 & 34 & freshwater & Lake Constance, Germany & $10-35$ & NGG. Ecoli. intrinsic growth rate. polynomial regression fit & 0.31 & This study \\
\hline Plectus aquatilis & 10 & 25 & 32 & freshwater & Lake Constance, Germany & $10-35$ & NGG. Ecoli. intrinsic growth rate. polynomial regression fit & 0.31 & This study \\
\hline Plectus opisthocirculus & 10 & 25 & 30 & freshwater & Lake Constance, Germany & $10-35$ & NGG. Ecoli. intrinsic growth rate. polynomial regression fit & 0.10 & This study \\
\hline Acrobeloides nanus & $<15$ & $>25$ & $>30$ & soil & Wageningen, The Netherlands & $15-25$ & NGM. Ecoli $20^{\circ} \mathrm{C}$. DEBtox fit to estimate growth rate & $0.5^{* *}$ & Ál varez et al. 2006 \\
\hline Bursilla labiata & 10.7 & 25.6 & 33.7 & soil & CA, USA & $10-35$ & NGM. Ecoli. Schoolfield's poikilotherm model & $0.6^{*}$ & Venette \& Ferris 1997 \\
\hline Acrobeloides buetschlii & 11.9 & 26.6 & 33.9 & soil & CA, USA & $10-35$ & NGM. Ecoli. Schoolfield's poikilotherm model & $0.5^{*}$ & Venette \& Ferris 1997 \\
\hline Acrobeloides nanus & $<10$ & 27 & $>35$ & soil & Berzdorf, Germany & $10-35$ & NGG. Ecoli. intrinsic growth rate. polynomial regression fit & 0.42 & This study \\
\hline Panagrolaimus var NFS 25-5 & $<21$ & 27 & $>29$ & soil & USA & $21-29$ & NGG. Ecoli. Intrinsic growth rate & 0.93 & Ayub et al. 2013 \\
\hline Acrobeloides bodenheimeri & 10.5 & 29.2 & 34.7 & soil & CA, USA & $10-35$ & NGM. Ecoli. Schoolfield's poikilotherm model & $0.6^{*}$ & Venette \& Ferris 1997 \\
\hline Cephalobus persegnis & 5.8 & 32.2 & 42.4 & soil & CA, USA & $10-35$ & NGM. Ecoli. Schoolfield's poikilotherm model & $0.5^{*}$ & Venette \& Ferris 1997 \\
\hline
\end{tabular}

$n d$ not determined $*$ approximated from graphical data and hourly rate $\quad * *$ max $\mathrm{r}$ measured at $20^{\circ} \mathrm{C}$ without exposure to chemicals 
Overall, the rates of population growth as well as the thermal tolerance ranges and optima determined in our study are in good agreement with the results of the few other studies investigating the impact of a broad spectrum of temperatures on free-living bacterivorous nematodes (Table 1). Despite the different methodological approaches used by different research groups to culture nematode strains and calculate population growth rates, some agreement might emerge from comparisons of the present study with the literature. For example, the species from the family Cephalobidae, to which the genus Acrobeloides belongs, seem noteworthy in their capacity to tolerate relatively high temperatures $\left(>25^{\circ} \mathrm{C}\right)$ (Table 1). This pattern matches well with compelling evidence that Cephalobidae are typical inhabitants of dry and arid soils (Steinberger et al., 1984; Freckman et al., 1987; Andrássy, 2005).

Mature females of the nematode species included in this study tended to be smaller and to produce fewer eggs at warmer temperatures. The number of eggs in the uterus was contingent upon the body-size of the female, as demonstrated by the positive linear relationship between these two parameters $\left(\mathrm{R}^{2}=0.36, \mathrm{~N}=420\right)$. That nematode adults tended to be smaller with increasing temperature is in general agreement with the temperature-size-rule. According to this rule, ectothermic organisms reach a smaller size at maturity in response to warming (e.g. Huntley and Lopez, 1992; Atkinson, 1995; Daufresne et al., 2009; Gardner et al., 2011; Forster et al., 2012). This trend may be even more pronounced in aquatic habitats because the availability of dissolved oxygen is also a crucial driver of temperature-size responses (Forster et al., 2012). In the case of bacterivorous nematode populations, it is well-known that females can mature at smaller sizes under food stress (Sudhaus, 1980; Schiemer et al., 1980; Schiemer 1982; dos Santos et al., 2008). This strategy is thought to shorten the immature life period and thus the costs for attaining maturity (Schiemer et al. 1980). In field populations, a general decrease of the body-size spectrum with warming-stress would presumably have far-reaching consequences on trophic transfers since nematodes are food for many other organisms (Yeates et al., 1993; Majdi and Traunspurger, 2015). For example, an experimental field warming can dramatically affect body-size and trophic structure of soil communities in Antarctica's dry valleys as it slightly increases the density of a small bacterivorous nematode species (Scottnema lindsayae, while it strongly decreases the densities of a larger omnivorous-predacious species (Eudorylaimus antarcticus) (Freckman and Virginia, 1997). At the scale of population sizestructure, the results obtained for A. nanus support the hypothesis of Daufresne et al. (2009), that warming induces a decrease in the mean body-size of a population due to a higher proportion of juvenile stages. In addition, our result also agreed with Jager et al. (2005) showing that $A$. nanus starts to produce eggs at a smaller size under higher temperatures. Consequently, on the other hand, populations of nematode species with a longer life cycle, such as Plectus spp., should be more sensitive to the effects of climate change (Ruess et al., 1999). Since bodysize is a key parameter in the structuring of ecological communities (Woodward et al., 2005), the ecological role of free-living nematodes will be accordingly presumably altered. 


\section{CONCLUSION}

Thermal pollution is one of the many anthropogenic alterations of ecosystems, and the frequency and severity of extreme climatic events such as heat waves are likely to increase with global climate warming. Ruess et al. (1999) suggested that temperature changes will alter nematode community structure, by reducing the dominance of some species and promoting that of others. In our study, populations of widespread bacterivorous nematodes varied in their responses to a broad range of temperatures, evidenced as changes in the growth and sizestructure of the five species tested. These results demonstrate that changes in the thermal regime have the potential to alter the population dynamics of free-living nematodes. The implications extend to the ecosystem level, since nematodes are basal key-consumers in biofilms, soils and aquatic sediments, thereby contributing to global nutrient cycles and fueling higher trophic levels. To better forecast the response of nematode communities to changes in the thermal regime, the effect of temperature should be examined under more realistic conditions, including different culture media, different food concentrations and quality, and different conditions of coexistence with competitors and predators (see e.g. Vafeiadou et al. 2018, Gansfort et al. 2018).

\section{ACKNOWLEDGMENTS}

We are grateful to Stefanie Gehner for technical assistance, and to two anonymous reviewers for helpful comments. This study is part of the RivEcoThermS (River Ecosystems under Thermal Stress) project funded by Electricité de France (EDF). The authors have no conflict of interest to declare.

\section{REFERENCES}

Álvarez, O.A., Jager, T., Redondo, E.M., Kammenga, J.E., 2006. Physiological modes of action of toxic chemicals in the nematode Acrobeloides nanus. Environmental Toxicology and Chemistry 25, 3230-3237.

Anderson, R.V., Coleman, D.C., 1982. Nematode temperature responses: a niche dimension in populations of bacterial-feeding nematodes. Journal of Nematology 14, 69-76.

Andrássy, I., 1956. Die Rauminhalts-und Gewichtsbestimmung der Fadenwürmer (Nematoden). Acta Zoologica Hungarica 2, 1-5.

Andrássy, I., 2005. Free-living nematodes of Hungary. in I. Pedozoologica Hungarica N³. Csuzdi, C., Mahunka, S. (Eds). 518 pp. Mondat Ltd., Budapest, Hungary.

Angilletta Jr, M.J., Steury, T.D., Sears, M.W., 2004. Temperature, growth rate, and body size in ectotherms: fitting pieces of a life-history puzzle. Integrative and comparative biology 44, 498509.

Atkinson, D., 1995. Effects of temperature on the size of aquatic ectotherms: exceptions to the general rule. Journal of Thermal Biology 20, 61-74.

Ayub, F., Strauch, O., Seychelles, L., Ehlers, R.-U., 2013. Influence of temperature on life history traits of the free-living, bacterial-feeding nematode Panagrolaimus sp. strain NFS-24. Nematology 15, 939-946.

Baldwin, J.G., Perry, R.N., 2004. Nematode morphology, sensory structure and function. Nematology: Advances and Perspectives 1, 175-257.

Benjamini, Y., Yekutieli, D., 2001. The control of the false discovery rate in multiple testing under 
dependency. Annals of Statistics 1165-1188.

Bingemer, J., Hohberg, K., Schill, R.O., 2016. First detailed observations on tardigrade mating behaviour and some aspects of the life history of Isohypsibius dastychi Pilato, Bertolani \& Binda 1982 (Tardigrada, Isohypsibiidae). Zoological Journal of the Linnean Society 178, 856-862.

Birch, L., 1948. The intrinsic rate of natural increase of an insect population. Journal of Animal Ecology $15-26$.

Brinke, M., Heininger, P., Traunspurger, W., 2013. Effects of a bioassay-derived ivermectin lowest observed effect concentration on life-cycle traits of the nematode Caenorhabditis elegans. Ecotoxicology 22, 148-155.

Daufresne, M., Lengfellner, K., Sommer, U., 2009. Global warming benefits the small in aquatic ecosystems. Proceedings of the National Academy of Sciences 106, 12788-12793.

dos Santos, G.A.P., Derycke, S., Fonsêca-Genevois, V.G., Coelho, L.C.B.B., Correia, M.T.S., Moens, T., 2008. Differential effects of food availability on population growth and fitness of three species of estuarine, bacterial-feeding nematodes. Journal of Experimental Marine Biology and Ecology $335,27-40$.

Forster, J., Hirst, A.G., Atkinson, D., 2012. Warming-induced reductions in body size are greater in aquatic than terrestrial species. Proceedings of the National Academy of Sciences 109, 19310 19314.

Freckman, D.W., Whitford, W.G., Steinberger, Y. 1987. Effect of irrigation on nematode population dynamics and activity in desert soils. Biology and Fertility of Soils 3, 3-10.

Freckman, D.W., Virginia, R.S. 1997. Low-diversity antarctic soil nematode communities: Distribution and response to disturbance. Ecology 78, 363-369.

Gansfort, B., Uthoff, J., Traunspurger, W., 2018. Interactions among competing nematode species affect population growth rates. Oecologia 187, 75-84.

Gardner, J.L., Peters, A., Kearney, M.R., Joseph, L., Heinsohn, R., 2011. Declining body size: a third universal response to warming? Trends in Ecology and Evolution 26, 285-291.

Hopper, B.E., Fell, J.W., Cefalu, R.C., 1973. Effect of temperature on life cycles of nematodes associated with the mangrove (Rhizophora mangle) detrital system. Marine Biology 23, 293-296.

Huntley, M.E., Lopez, M.D., 1992. Temperature-dependent production of marine copepods: a global synthesis. The American Naturalist 140, 201-242.

IPCC, 2014. Climate Change 2014: Synthesis Report. Contribution of working groups I, II and III to the fifth assessment report of the Intergovernmental Panel on Climate Change. IPCC.

Jager, T., Álvarez, O.A., Kammenga, J.E., Kooijman, S., 2005. Modelling nematode life cycles using dynamic energy budgets. Functional Ecology 19, 136-144.

Kim, H., Rho, H.S., Oh, C.-W., 2013. Seasonal and spatial variations in nematode assemblages affected by thermal influence of nuclear power plant in Korea (East Sea, Pacific Ocean). Marine Biology Research 9, 725-738.

Kreuzinger-Janik, B., Brinke, M., Traunspurger, W., Majdi, N., 2017. Life history traits of the freeliving nematode, Plectus acuminatus Bastian, 1865, and responses to cadmium exposure. Nematology 19, 645-654.

Lee, D.L., 2002. Life cycles. in The biology of nematodes. Lee, D.L. (Ed). 61-72. CRC Press, Boca Raton, FL, USA.

Lindmark, M., Huss, M., Ohlberger, J., Gårdmark, A., 2018. Temperature-dependent body size effects determine population responses to climate warming. Ecology Letters 21, 181-189.

Majdi, N., Traunspurger, W., 2015. Free-living nematodes in the freshwater food web: a review. Journal of Nematology 47, 28-44.

McSorley, R., 2003. Adaptations of nematodes to environmental extremes. Florida Entomologist 86, $138-142$. 
Muschiol, D., Traunspurger, W., 2007. Life cycle and calculation of the intrinsic rate of natural increase of two bacterivorous nematodes, Panagrolaimus sp and Poikilolaimus sp from chemoautotrophic Movile Cave, Romania. Nematology 9, 271-284.

Moens, T., Vincx, M., 2000. Temperature and salinity constraints on the life cycle of two brackish-water nematode species. Journal of Experimental Marine Biology and Ecology 243, 115-135.

Ocaña, A., 1991. Relationship between nematode species and the physico-chemical characteristics of spring waters. II. Temperature. Nematologia Mediterranea 19, 25-28.

O’Gorman, E.J., Pichler, D.E., Adams, G., Benstead, J.P., Cohen, H., Craig, N., Cross, W.F., Demars, B.O., Friberg, N., Gislason, G.M., 2012. Impacts of warming on the structure and functioning of aquatic communities: individual-to ecosystem-level responses, in: Advances in Ecological Research. Elsevier, pp. 81-176.

Pillai, J.K., Taylor, D.P., 1967. Effect of temperature on the time required for hatching and duration of life cycle of five mycophagous nematodes. Nematologica 13, 512-516.

R Development Core Team, 2018. R: A language and environment for statistical computing. R Foundation for Statistical Computing. Retrieved from http://R-project.org, Vienna, Austria.

Ricklefs, R.E., Miller, G.L., 1999. Ecology. Fourth Edition. Freeman, New York.

Ruess, L., Michelsen, A., Jonasson, S., 1999. Simulated climate change in subarctic soils: responses in nematode species composition and dominance structure. Nematology 1, 513-526.

Sandhove, J., Spann, N., Ristau, K., 2016. The anhydrobiotic potential of the terrestrial nematodes Plectus parietinus and Plectus velox. Journal of Experimental Zoology Part A 325, 434-440.

Savage, V.M., Gillooly, J.F., Brown, J.H., West, G.B., Charnov, E.L., 2004. Effects of body size and temperature on population growth. The American Naturalist 163, 429-441.

Schiemer, F., 1982. Food dependence and energetics of free-living nematodes. I. Respiration, growth and reproduction of Caenorhabditis briggsae (Nematoda) at different levels of food supply. Oecologia 54, 108-121.

Schiemer, F., Duncan, A., Klekowski, R.Z., 1980. A bioenergetic study of a benthic nematode, Plectus palustris de Man 1880, throughout its life cycle. II. Growth, fecundity and energy budgets at different densities of bacterial food and general ecological considerations. Oecologia 44, 205212.

Seinhorst, J.W., 1959. A rapid method for the transfer of nematodes from fixative to anhydrous glycerin. Nematologica 4, 67-69.

Sharpe, P.J., DeMichele, D.W., 1977. Reaction kinetics of poikilotherm development. Journal of Theoretical Biology 64, 649-670.

Sibly, R.M., Hone, J., 2002. Population growth rate and its determinants: an overview. Philosophical Transactions of the Royal Society B 357, 1153-1170.

Smith, T., Wharton, D.A., Marshall, C.J., 2008. Cold tolerance of an Antarctic nematode that survives intracellular freezing: comparisons with other nematode species. Journal of Comparative Physiology B 178, 93-100.

Sohlenius, B., 1968. Influence of micro-organisms and temperature upon some rhabditid nematodes. Pedobiologia 8, 137-145.

Sohlenius, B., Boström, S., Hirschfelder, A., 1995. Nematodes, rotifers and tardigrades from nunataks in Dronning Maud Land, East Antarctica. Polar Biology 15, 51-56.

Steinberger, Y., Freckman, D.W., Parker, L.W., Whitford, W.G., 1984. Effects of simulated rainfall and litter quantities on desert soil biota: Nematodes and microarthropods. Pedobiologia 26, 267-274.

Sudhaus, W., 1980. Systematisch-phylogenetische und biologisch-ökologische Untersuchungen an Rhabditis- (Poikilolaimus-) Arten als Beitrag zu Rassenbildung und Parallelevolution bei Nematoden. Zoologische Jahrbücher (Systematik) 107, 287-343.

Tahseen, Q., 2012. Nematodes in aquatic environments: adaptations and survival strategies. Biodiversity 
Journal 3, 13-40.

Traunspurger, W., 2000. The biology and ecology of lotic nematodes. Freshwater Biology 44, 29-45.

Trudgill, D.L., Perry, J.N., 1994. Thermal time and ecological strategies-a unifying hypothesis. Annals of Applied Biology 125, 521-532.

Vafeiadou, A.-M., Chintiroglou, C., Moens, T., 2018. Effects of an increased temperature regime on the population dynamics and species interactions of marine nematodes. Journal of Experimental Marine Biology and Ecology 502, 142-152.

Van der Have, T.M., De Jong, G., 1996. Adult size in ectotherms: temperature effects on growth and differentiation. Journal of theoretical biology 183, 329-340.

Venette, R.C., Ferris, H., 1997. Thermal constraints to population growth of bacterial-feeding nematodes. Soil Biology and Biochemistry 29, 63-74.

Warwick, R.M., 1981. The influence of temperature and salinity on energy partitioning in the marine nematode Diplolaimelloides bruciei. Oecologia 51, 318-325.

Wharton, D.A., 2002. Nematode survival strategies. in The biology of nematodes. Lee, D.L. (Ed). 389411. CRC Press, Boca Raton, FL, USA.

Wieser, W., 1960. Benthic Studies in Buzzards Bay. II. The Meiofauna. Limnology and Oceanography $5,121-137$.

Woodward, G., Ebenman, B., Emmerson, M., Montoya, J.M., Olesen, J.M., Valido, A., Warren, P.H., 2005. Body size in ecological networks. Trends in Ecology and Evolution 20, 402-409.

Woodward, G., Perkins, D.M., Brown, L.E., 2010. Climate change and freshwater ecosystems: impacts across multiple levels of organization. Philosophical Transactions of the Royal Society B 365, 2093-2106.

Woodward, G., Bonada, N., Brown, L.E., Death, R.G., Durance, I., Gray, C., Hladyz, S., Ledger, M.E., Milner, A.M., Ormerod, S.J., 2016. The effects of climatic fluctuations and extreme events on running water ecosystems. Philosophical Transactions of the Royal Society B 371, 2015-0274.

Yeates, G.W., Boag, B., 2003. Growth and life histories in Nematoda with particular reference to environmental factors. Nematology 5, 653-664.

Yeates, G.W., Bongers, T. d, De Goede, R.G.M., Freckman, D.W., Georgieva, S.S., 1993. Feeding habits in soil nematode families and genera - an outline for soil ecologists. Journal of Nematology $25,315$.

Yeates, G.W., Ferris, H., Moens, T., Van der Putten, W.H., 2009. The role of nematodes in ecosystems. Nematodes as Environmental Bioindicators 1-44. 
Majdi N. et al. (2019) Effects of a broad range of experimental temperatures on the population growth and bodysize of five species of free-living nematodes. Journal of Thermal Biology, in press.

\section{APPENDICES}

\section{Appendix A. Experiment design}

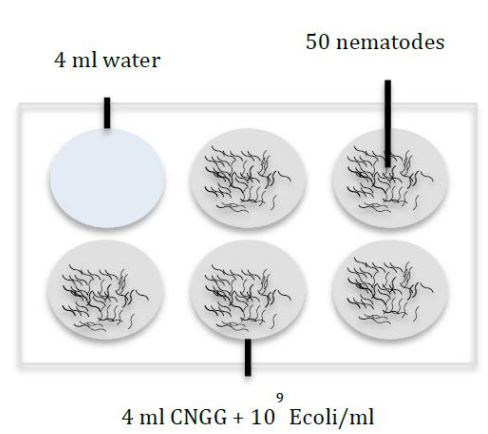

Incubation during $20 \mathrm{~d}$ at
$10 / 15 / 20 / 25 / 30 / 35^{\circ} \mathrm{C}$

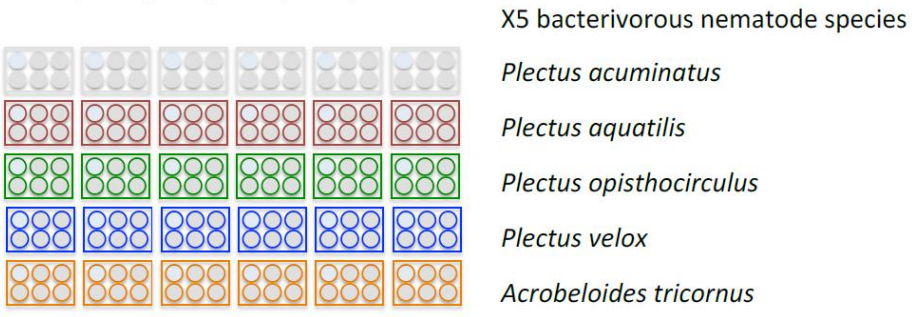

Fig A.1. Schematic representation of an experimental plate at T0 (left panel) and of the full experimental design (right panel). 
Majdi N. et al. (2019) Effects of a broad range of experimental temperatures on the population growth and bodysize of five species of free-living nematodes. Journal of Thermal Biology, in press.

\section{Appendix B. Univariate results of the statistical tests \& additional figure}

Table B.1. Comparison of growth rates of each nematode species across a temperature gradient $\left(10^{\circ} \mathrm{C}\right.$ to $35^{\circ} \mathrm{C}$ ). Bold values correspond to significant differences.

\begin{tabular}{cccc}
$\begin{array}{c}\text { Plectus acuminatus } \\
\text { "comparisons" }\end{array}$ & \multicolumn{2}{c}{ Kruskal-Wallis chi-squared $=$} \\
& & "P" & p adjusted holm \\
\hline $10-15$ & -1.65 & 0.0492 & 0.3446 \\
$\mathbf{1 0 - 2 0}$ & -2.73 & 0.0032 & $\mathbf{0 . 0 3 8 0}$ \\
$15-20$ & -1.07 & 0.1406 & 0.7030 \\
$\mathbf{1 0 - 2 5}$ & -3.34 & 0.0004 & $\mathbf{0 . 0 0 5 4}$ \\
$15-25$ & -1.68 & 0.0457 & 0.3654 \\
$20-25$ & -0.61 & 0.2707 & 0.2707 \\
$10-30$ & -0.68 & 0.2475 & 0.4949 \\
$15-30$ & 0.96 & 0.1661 & 0.6642 \\
$20-30$ & 2.04 & 0.0203 & 0.1827 \\
$\mathbf{2 5 - 3 0}$ & 2.65 & 0.0039 & $\mathbf{0 . 0 4 3 2}$ \\
$10-35$ & 0.96 & 0.1661 & 0.4982 \\
$\mathbf{1 5 - 3 5}$ & 2.62 & 0.0044 & $\mathbf{0 . 0 4 3 7}$ \\
$\mathbf{2 0 - 3 5}$ & 3.69 & 0.0001 & $\mathbf{0 . 0 0 1 5}$ \\
$\mathbf{2 5 - 3 5}$ & 4.31 & 0.0000 & $\mathbf{0 . 0 0 0 1}$ \\
$30-35$ & 1.65 & 0.0492 & 0.2954 \\
\hline
\end{tabular}

\begin{tabular}{cccc}
$\begin{array}{c}\text { Plectus aquatilis } \\
\text { "comparisons" }\end{array}$ & "Z" & \multicolumn{2}{c}{ Kruskal-Wallis chi-squared $=$} \\
\hline $10-15$ & -1.43 & 0.0754 & p adjusted holm \\
$10-20$ & -2.55 & 0.0054 & 0.4522 \\
$15-20$ & -1.11 & 0.1327 & 0.6635 \\
$\mathbf{1 0 - 2 5}$ & -3.44 & 0.0003 & $\mathbf{0 . 0 0 3 7}$ \\
$15-25$ & -2.01 & 0.0221 & 0.1991 \\
$20-25$ & -0.89 & 0.1846 & 0.5537 \\
$10-30$ & -0.82 & 0.2043 & 0.4086 \\
$15-30$ & 0.61 & 0.2707 & 0.2707 \\
$20-30$ & 1.72 & 0.0423 & 0.2962 \\
$25-30$ & 2.62 & 0.0044 & 0.0524 \\
$10-35$ & 1.04 & 0.1487 & 0.5950 \\
$15-35$ & 2.47 & 0.0066 & 0.0659 \\
$\mathbf{2 0 - 3 5}$ & 3.59 & 0.0002 & $\mathbf{0 . 0 0 2 3}$ \\
$\mathbf{2 5 - 3 5}$ & 4.49 & 0.0000 & $\mathbf{0 . 0 0 0 1}$ \\
$30-35$ & 1.86 & 0.0309 & 0.2470 \\
\hline
\end{tabular}


Majdi N. et al. (2019) Effects of a broad range of experimental temperatures on the population growth and bodysize of five species of free-living nematodes. Journal of Thermal Biology, in press.

Plectus opisthocirculus $\quad$ Kruskal-Wallis chi-squared $=25.97 . \mathrm{df}=5 . \mathrm{p}$-value $<0.001$

\begin{tabular}{cccc} 
"comparisons" & "Z" & "P" & p adjusted holm \\
\hline $10-15$ & -1.41 & 0.0779 & 0.5456 \\
$\mathbf{1 0 - 2 0}$ & -2.64 & 0.0041 & $\mathbf{0 . 0 4 5 5}$ \\
$15-20$ & -1.22 & 0.1110 & 0.5548 \\
$\mathbf{1 0 - 2 5}$ & -2.89 & 0.0019 & $\mathbf{0 . 0 2 4 9}$ \\
$15-25$ & -1.47 & 0.0704 & 0.5631 \\
$20-25$ & -0.25 & 0.4007 & 0.8014 \\
$10-30$ & 0.00 & 0.5000 & 0.5000 \\
$15-30$ & 1.41 & 0.0779 & 0.4677 \\
$\mathbf{2 0 - 3 0}$ & 2.64 & 0.0041 & $\mathbf{0 . 0 4 1 4}$ \\
$\mathbf{2 5 - 3 0}$ & 2.89 & 0.0019 & $\mathbf{0 . 0 2 3 0}$ \\
$10-35$ & 1.13 & 0.1289 & 0.5156 \\
$\mathbf{1 5 - 3 5}$ & 2.55 & 0.0054 & $\mathbf{0 . 0 4 8 4}$ \\
$\mathbf{2 0 - 3 5}$ & 3.77 & 0.0001 & $\mathbf{0 . 0 0 1 1}$ \\
$\mathbf{2 5 - 3 5}$ & 4.02 & 0.0000 & $\mathbf{0 . 0 0 0 4}$ \\
$30-35$ & 1.13 & 0.1289 & 0.3867 \\
\hline
\end{tabular}

Plectus cf. velox Kruskal-Wallis chi-squared $=23.694 . \mathrm{df}=5 . \mathrm{p}$ - value $<0.001$

\begin{tabular}{cccc} 
"comparisons" & "Z" & "P" & p adjusted holm \\
\hline $10-15$ & -0.17 & 0.4287 & 0.4287 \\
$10-20$ & 0.75 & 0.2253 & 0.6760 \\
$15-20$ & 0.93 & 0.1752 & 0.8758 \\
$10-25$ & 1.65 & 0.0492 & 0.3446 \\
$15-25$ & 1.83 & 0.0335 & 0.3013 \\
$20-25$ & 0.89 & 0.1846 & 0.7383 \\
$\mathbf{1 0 - 3 0}$ & 3.05 & 0.0011 & $\mathbf{0 . 0 1 3 6}$ \\
$\mathbf{1 5 - 3 0}$ & 3.23 & 0.0006 & $\mathbf{0 . 0 0 8 0}$ \\
$20-30$ & 2.29 & 0.0108 & 0.1075 \\
$25-30$ & 1.40 & 0.0806 & 0.4837 \\
$\mathbf{1 0 - 3 5}$ & 3.44 & 0.0003 & $\mathbf{0 . 0 0 3 9}$ \\
$\mathbf{1 5 - 3 5}$ & 3.62 & 0.0001 & $\mathbf{0 . 0 0 2 1}$ \\
$\mathbf{2 0 - 3 5}$ & 2.69 & 0.0035 & $\mathbf{0 . 0 3 8 8}$ \\
$25-35$ & 1.79 & 0.0362 & 0.2899 \\
$30-35$ & 0.39 & 0.3464 & 0.6927 \\
\hline
\end{tabular}


Majdi N. et al. (2019) Effects of a broad range of experimental temperatures on the population growth and bodysize of five species of free-living nematodes. Journal of Thermal Biology, in press.

\begin{tabular}{cccc}
\multicolumn{2}{c}{ Acrobeloides nanus } & \multicolumn{2}{c}{ Kruskal-Wallis chi-squared $=$} \\
"comparisons" & "Z" & 'P" & p adjusted holm \\
\hline $10-15$ & -1.40 & 0.0806 & 0.4837 \\
$10-20$ & -2.37 & 0.0089 & 0.0888 \\
$15-20$ & -0.96 & 0.1661 & 0.4982 \\
$\mathbf{1 0 - 2 5}$ & -3.62 & 0.0001 & $\mathbf{0 . 0 0 2 0}$ \\
$15-25$ & -2.22 & 0.0130 & 0.1167 \\
$20-25$ & -1.25 & 0.1043 & 0.5217 \\
$\mathbf{1 0 - 3 0}$ & -3.80 & 0.0001 & $\mathbf{0 . 0 0 1 1}$ \\
$15-30$ & -2.40 & 0.0080 & 0.0885 \\
$20-30$ & -1.43 & 0.0754 & 0.5277 \\
$25-30$ & -0.17 & 0.4287 & 0.4287 \\
$10-35$ & -0.32 & 0.3732 & 0.7465 \\
$15-35$ & 1.07 & 0.1406 & 0.5624 \\
$20-35$ & 2.04 & 0.0203 & 0.1624 \\
$\mathbf{2 5 - 3 5}$ & 3.30 & 0.0005 & $\mathbf{0 . 0 0 5 7}$ \\
$\mathbf{3 0 - 3 5}$ & 3.48 & 0.0002 & $\mathbf{0 . 0 0 3 2}$ \\
\hline
\end{tabular}


Table B.2. Comparison of the growth rate of 5 nematode species (Acrobeloides nanus: nan. Plectus acuminatus: acu. Plectus aquatilis: aqu. Plectus opisthocirculus: opi. Plectus cf. velox: vel) at each temperature. Bold values correspond to significant differences.

\begin{tabular}{rlll}
10 & \multicolumn{3}{c}{ Kruskal-Wallis chi-squared $=16.689 . \mathrm{df}=4 . \mathrm{p}$-val } \\
comparisons & $\mathrm{Z}$ & $\mathrm{P}$ & $\mathrm{p}$ adjusted holm \\
\hline nan-acu & -0.64 & 0.259 & 0.519 \\
nan-aqu & 1.93 & 0.026 & 0.159 \\
acu-aqu & 2.57 & 0.004 & $\mathbf{0 . 0 3 9}$ \\
nan-opi & 1.50 & 0.066 & 0.265 \\
acu-opi & 2.14 & 0.015 & 0.110 \\
aqu-opi & -0.42 & 0.333 & 0.333 \\
nan-vel & -1.50 & 0.066 & 0.331 \\
acu-vel & -0.85 & 0.195 & 0.585 \\
aqu-vel & -3.43 & 0.0002 & $\mathbf{0 . 0 0 2}$ \\
opi-vel & -3.00 & 0.001 & $\mathbf{0 . 0 1 1}$ \\
\hline
\end{tabular}

\section{$\mathbf{1 5}^{\circ} \mathbf{C} \quad$ Kruskal - Wallis chi-squared $=16.32 . \mathrm{df}=4 . \mathrm{p}$-value $=0.002$}

\begin{tabular}{rlll} 
comparisons & $\mathrm{Z}$ & $\mathrm{P}$ & $\mathrm{p}$ adjusted holm \\
\hline nan-acu & -1.67 & 0.046 & 0.234 \\
nan-aqu & 0.30 & 0.381 & 0.381 \\
acu-aqu & 1.97 & 0.024 & 0.168 \\
nan-opi & 2.27 & 0.011 & 0.091 \\
acu-opi & 3.95 & 0.00003 & $\mathbf{0 . 0 0 0 3}$ \\
aqu-opi & 1.97 & 0.024 & 0.144 \\
nan-vel & 0.81 & 0.207 & 0.621 \\
acu-vel & 2.49 & 0.006 & 0.057 \\
aqu-vel & 0.51 & 0.303 & 0.606 \\
opi-vel & -1.46 & 0.072 & 0.288 \\
\hline
\end{tabular}

$\mathbf{2 0}^{\circ} \mathbf{C}$ Kruskal-Wallis chi-squared $=21.43 . \mathrm{df}=4$. $\mathrm{p}$ - value $<0.001$

\begin{tabular}{rlll} 
comparisons & $\mathrm{Z}$ & $\mathrm{P}$ & $\mathrm{p}$ adjusted holm \\
\hline nan-acu & 1.37 & 0.084 & 0.253 \\
nan-aqu & 1.71 & 0.042 & 0.214 \\
acu-aqu & 0.34 & 0.365 & 0.365 \\
nan-opi & 3.26 & 0.0005 & $\mathbf{0 . 0 0 4}$ \\
acu-opi & 1.89 & 0.029 & 0.176 \\
aqu-opi & 1.54 & 0.060 & 0.243 \\
nan-vel & 4.16 & 0.00001 & $\mathbf{0 . 0 0 0 1}$ \\
acu-vel & 2.79 & 0.002 & $\mathbf{0 . 0 2 0}$ \\
aqu-vel & 2.44 & 0.007 & 0.0501 \\
opi-vel & 0.90 & 0.183 & 0.366 \\
\hline
\end{tabular}


Majdi N. et al. (2019) Effects of a broad range of experimental temperatures on the population growth and bodysize of five species of free-living nematodes. Journal of Thermal Biology, in press.

$25^{\circ} \mathrm{C} \quad$ Kruskal-Wallis chi-squared $=21.94 . \mathrm{df}=4$. $\mathrm{p}$-value $<0.001$

\begin{tabular}{rlll} 
comparisons & $\mathrm{Z}$ & $\mathrm{P}$ & $\mathrm{p}$ adjusted holm \\
\hline nan-acu & 1.67 & 0.046 & 0.281 \\
nan-aqu & 1.54 & 0.060 & 0.243 \\
acu-aqu & -0.12 & 0.448 & 0.448 \\
nan-opi & 3.22 & 0.0006 & $\mathbf{0 . 0 0 5}$ \\
acu-opi & 1.54 & 0.060 & 0.182 \\
aqu-opi & 1.67 & 0.046 & 0.234 \\
nan-vel & 4.29 & 0.000008 & $\mathbf{0 . 0 0 0 0 8}$ \\
acu-vel & 2.62 & 0.004 & $\mathbf{0 . 0 3 0}$ \\
aqu-vel & 2.74 & 0.002 & $\mathbf{0 . 0 2 3}$ \\
opi-vel & 1.07 & 0.141 & 0.282 \\
\hline
\end{tabular}

$\mathbf{3 0}^{\circ} \mathbf{C} \quad$ Kruskal-Wallis chi-squared $=20.034 . \mathrm{df}=4 . \mathrm{p}$-value $<0.001$

\begin{tabular}{rlll} 
comparisons & $\mathrm{Z}$ & $\mathrm{P}$ & $\mathrm{p}$ adjusted holm \\
\hline nan-acu & 1.37 & 0.084 & 0.338 \\
nan-aqu & 2.10 & 0.017 & 0.123 \\
acu-aqu & 0.73 & 0.232 & 0.232 \\
nan-opi & 3.17 & 0.0007 & $\mathbf{0 . 0 0 6}$ \\
acu-opi & 1.80 & 0.035 & 0.177 \\
aqu-opi & 1.07 & 0.141 & 0.424 \\
nan-vel & 4.08 & 0.00002 & $\mathbf{0 . 0 0 0 2}$ \\
acu-vel & 2.70 & 0.003 & $\mathbf{0 . 0 2 7}$ \\
aqu-vel & 1.97 & 0.024 & 0.144 \\
opi-vel & 0.90 & 0.183 & 0.366 \\
\hline
\end{tabular}

$35^{\circ} \mathrm{C} \quad$ Kruskal-Wallis chi-squared $=14.681 . \mathrm{df}=4 . \mathrm{p}$-value $=0.005$

\begin{tabular}{rlll} 
comparisons & $\mathrm{Z}$ & $\mathrm{P}$ & $\mathrm{p}$ adjusted holm \\
\hline nan-acu & 1.54 & 0.060 & 0.303 \\
nan-aqu & 3.24 & 0.0005 & $\mathbf{0 . 0 0 5}$ \\
acu-aqu & 1.69 & 0.044 & 0.312 \\
nan-opi & 2.62 & 0.004 & $\mathbf{0 . 0 3 4}$ \\
acu-opi & 1.07 & 0.141 & 0.564 \\
aqu-opi & -0.62 & 0.266 & 0.799 \\
nan-vel & 3.11 & 0.0009 & 0.008 \\
acu-vel & 1.56 & 0.058 & 0.349 \\
aqu-vel & -0.12 & 0.448 & 0.448 \\
opi-vel & 0.49 & 0.310 & 0.620 \\
\hline
\end{tabular}



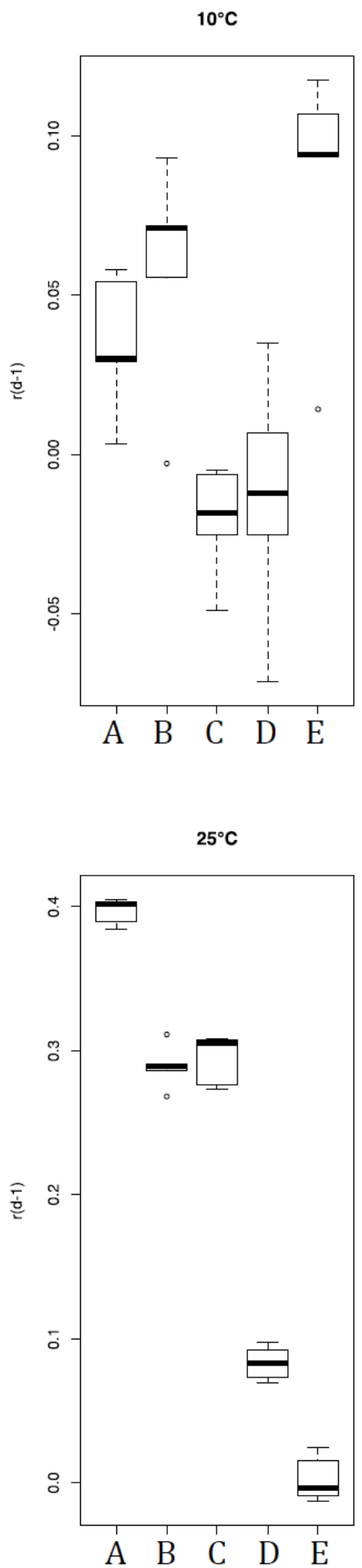
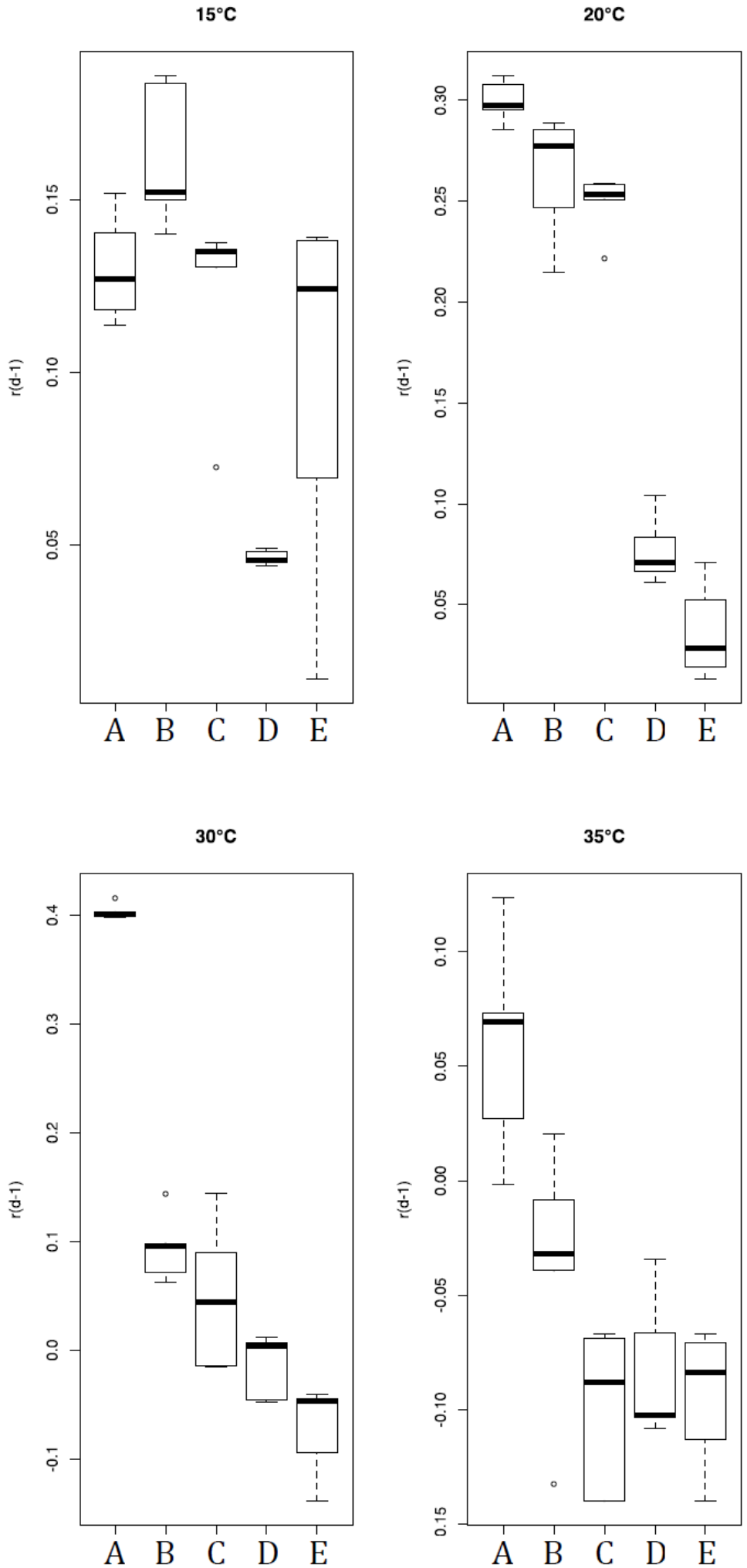

Fig B.1. Comparison of the population growth rates $(r)$ of five species of nematodes cultured at different temperatures (from 10 to $35^{\circ} \mathrm{C}$ ). (A) Acrobeloides nanus. (B) Plectus acuminatus. (C) Plectus aquatilis. (D) Plectus opisthocirculus. and (E) Plectus cf. velox. Values are medians. boxes are interquartile range. 


\section{Appendix C. Number of eggs and size at maturity}

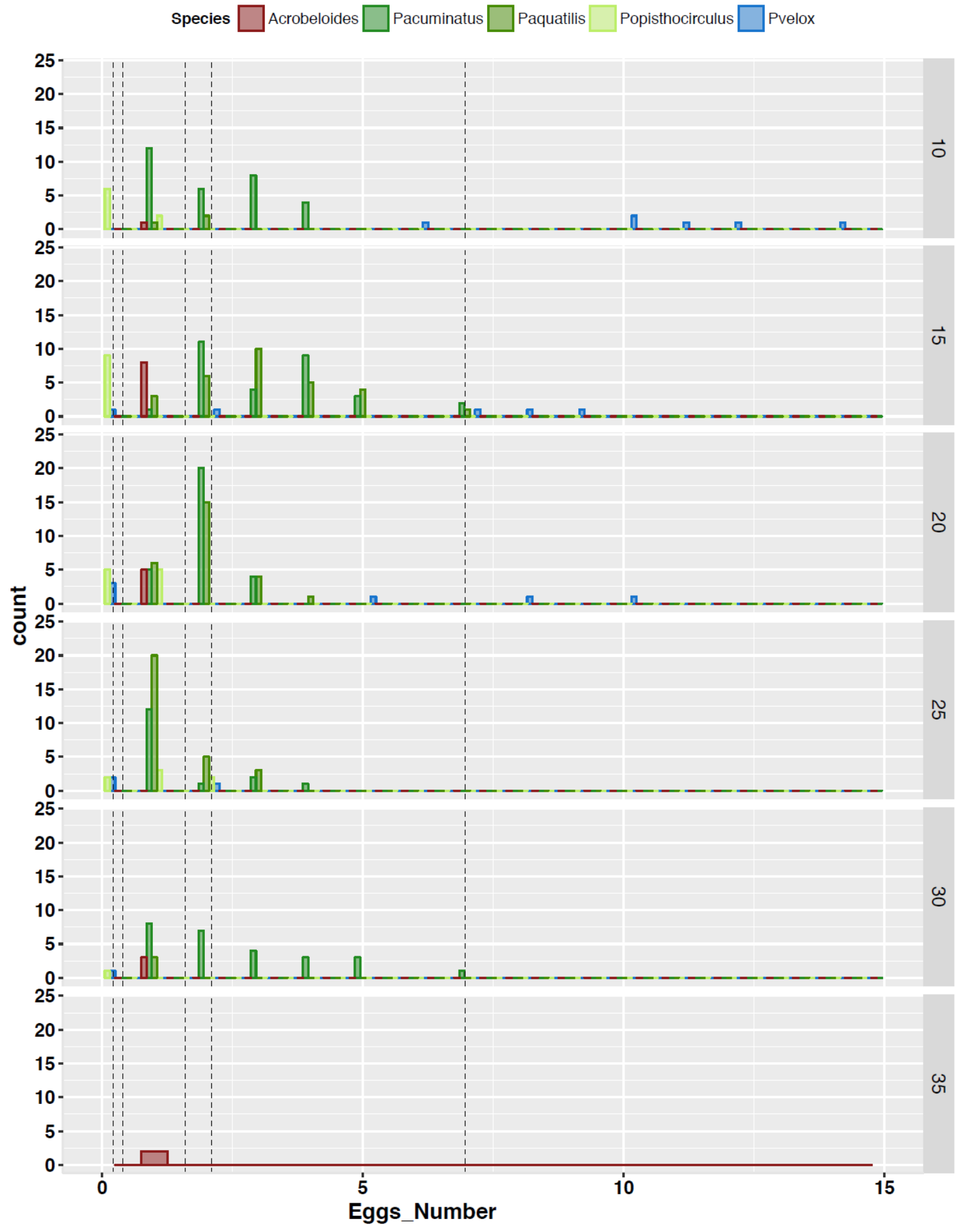

Fig C.1. Distribution of the number of eggs per mature females in five nematode species cultured under temperature conditions from 10 to $35^{\circ} \mathrm{C}$. black dotted lines showed mean number of eggs per gravide female (from the left to the right: Acrobeloides nanus: 0.2, Plectus opisthocirculus: 0.4, Plectus aquatilis: 1.6, Plectus acuminatus: 2.1, Plectus cf. velox: 6.9). 


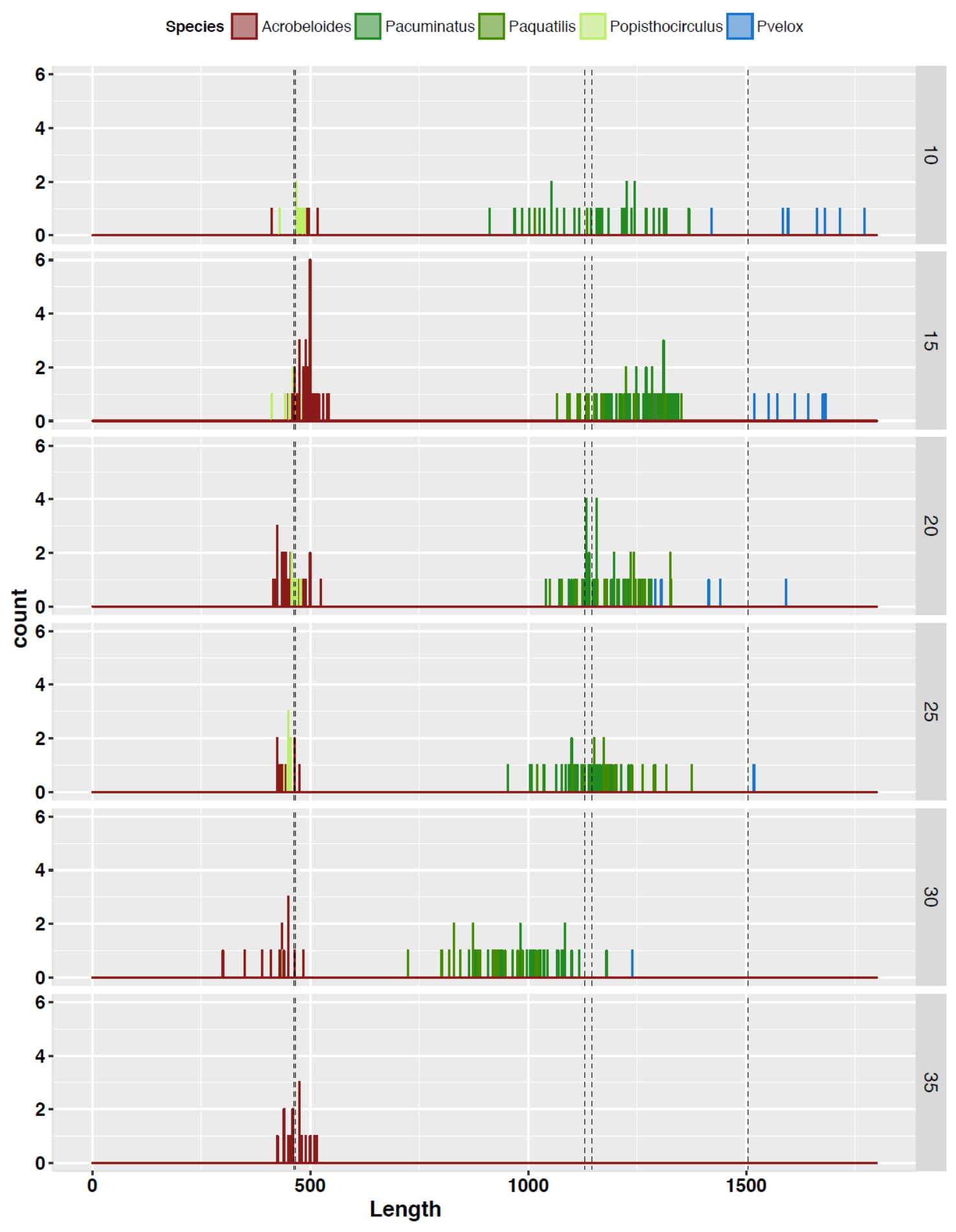

Fig C.2. Distribution of body-length $(\mu \mathrm{m})$ of mature females in five nematode species cultured under temperature conditions from 10 to $35^{\circ} \mathrm{C}$. black dotted lines showed mean length in $\mu \mathrm{m}$ (from the left to the right: Plectus opisthocirculus: 462.6, Acrobeloides nanus: 465.8, Plectus aquatilis: 1130.6, Plectus acuminatus: 1146.7, Plectus cf. velox: 1504.5). 


\section{Appendix D. Body-mass spectra of Acrobeloides nanus}

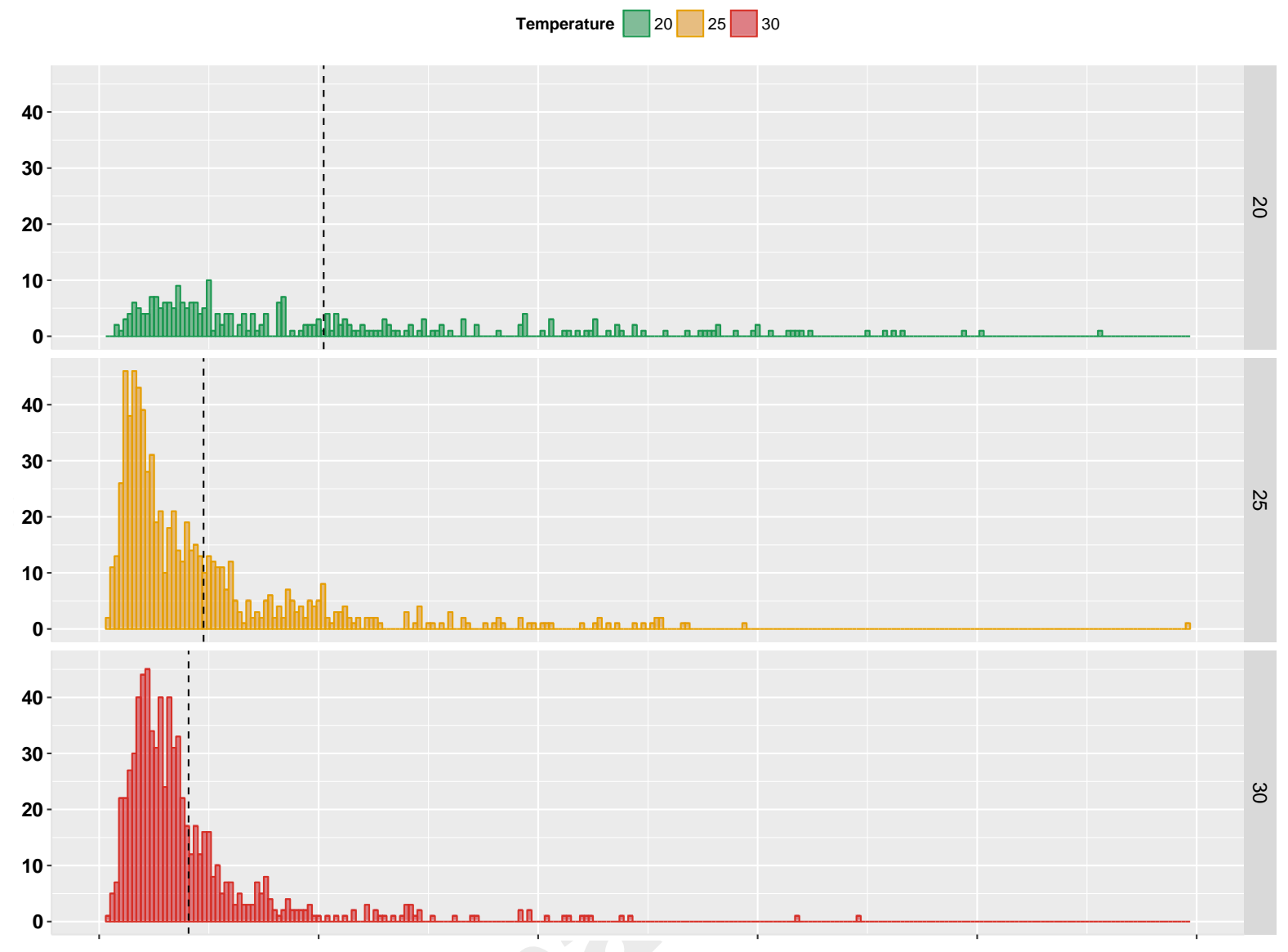

Fig D.1. Body-mass spectra of populations of Acrobeloides nanus cultured under temperature conditions from 20 to $30^{\circ} \mathrm{C}$. black dotted lines showed mean dry-weight in ng (from the left to the right: at $20^{\circ} \mathrm{C}: 10.2$, at $25^{\circ} \mathrm{C}: 4.75$, at $30^{\circ} \mathrm{C}: 4.07$ ). 